\title{
Who benefits from seafood trade? A comparison of social and market structures in small-scale fisheries
}

\author{
${\underline{E l i z a b e t h} \text { Drury } O^{\prime} \text { Neill }^{1}}^{1}$ Beatrice Crona $^{1,2}$, Alice Joan G. Ferrer $^{3}$, Robert Pomeroy $^{4}$ and Narriman S. Jiddawi $^{5}$
}

\begin{abstract}
We examine the benefits flowing from a coastal seascape through seafood trade to various social groups in two distinct small-scale fishery case studies. A knowledge gap currently exists in relation to how benefits from a fishery, and the associated trade, are ultimately distributed, specifically, how market structures and relations, and the combined dynamics of the local fishing society, can mediate these flows. Previous research into improved fisheries governance for food and livelihood security has failed to integrate the structure of the market place as well as the multidimensional nature of actor relations that influence extractive behavior. Using a value chain framework, we take a relational approach to study these gaps. Surveys were conducted in two fisheries (Zanzibar and the Philippines) as part of a comparative analysis including market-types, assistance networks, and income inequality. Chain structures, gender roles, and levels of contractualization within the two cases differed vastly, appearing to give rise to different types of income inequalities and barriers to participation. In the Philippines economic exchanges revolve more around provision of financial capital, although in both systems social standing and obligations play a role in determining market structures. In Zanzibar trading agents engaging customers in predetermined sale arrangements earn relatively more than their counterpart freelancers, however at the production level no income differences are seen between those with or without arrangements. Both cases stand to be further integrated into the international seafood market, which raises questions over how certain actors will benefit, based on their current participation and access. Results emphasize the need for more evidence in regards to benefits flows and how aspects such as gender and transaction forms impact them. This is necessary for governance decisions around fisheries, poverty alleviation, and increased global market integration.
\end{abstract}

Key Words: case studies; gender roles; global markets; Iloilo; income inequality; value chain participation; Zanzibar

\section{INTRODUCTION}

Small-scale fisheries (SSF) are frequently cited as necessary for sustainable poverty alleviation in coastal areas worldwide and a large body of literature exists discussing the connections between poverty, SSF seafood trade, food, and livelihood security (Béné 2003, Béné et al. 2004, 2010a,b, Islam 2011, Neiland and Béné 2013, Nayak et al. 2014). Although people benefit from their involvement in SSF markets, via access to protein, cash, and employment, development policies have often focused on economic growth and intensifying international seafood trade links (Béné et al. 2007). Although important, this focus does not appear to have markedly reduced poverty levels in many SSF (Béné et al. 2007). Case studies typically indicate that small-scale primary producers receive the lowest economic benefits relative to other value chain (VC) actors (Wamukota et al. 2014, Wamukota 2015, Bjørndal et al. 2015). In SSF exporting to international (often western) markets, there are particularly stark contrasts between benefits gained by local producers versus the corporate interests involved (Kurien 2005).

Recent research has highlighted the various attributes or contextual features that can impact benefit flows, such as gender, transaction forms, i.e., patron-client relationships, and buyer types, e.g., local or tourist (Ferrol-Schulte et al. 2014, Fröcklin 2014, Wamukota 2015). However, which groups (beyond fishers) benefit from SSF, and how such benefits are distributed, remains obscure. To address this, and to disentangle the market features and social mechanisms that impact SSF benefit flows and distribution, we ask: Who are the market chain actors and how do they benefit from SSF in two socio-politically distinct fisheries settings: Concepcion municipality in the Philippines (Iloilo Province) and Unguja Island of Zanzibar.

We pursue this analysis in four steps. First, to understand who is involved we employ a value chain (hereafter denoted VC) approach with a focus on gender and market interactions. A VC analysis is one way to examine market structures, i.e., identity, size, and numbers of traders/fishers and product-types they deal with, while also assessing the relationships among actors and subsequently understanding the market conduct, i.e., buying, selling, and pricing, this gives rise to. This type of analysis does not necessarily include cost or margin components but can be used for any number of governance objectives, which in this current study focused on relationships among actors in the market chain. Second, to assess benefit distribution, net income is first assessed across VC nodes (used here to define a step in the VC where a group of actors fulfill the same or a similar function within the chain, e.g., production, drying, retailing) and across gender. Next, levels of inequality within VC nodes/groups of nodes, gender, and across both countries are calculated. Finally, it is often argued that fishers' relations with trading agents (used here to refer to different types of actors buying and selling) can have an impact on fishers' conduct, decision making, and income, and thus, on the distribution of benefits stemming from seafood extraction and trade (Crona et al. 2010, Ferrol-Schulte et al. 2014, Drury O'Neill and Crona 2017). Yet, despite their seemingly

\footnotetext{
${ }^{1}$ Stockholm Resilience Centre, Stockholm University, Stockholm, Sweden, ${ }^{2}$ The Royal Swedish Academy of Sciences, Stockholm, Sweden, ${ }^{3}$ Division of Social Sciences, University of the Philippines Visayas, Miagao, Iloilo, Philippines, ${ }^{4}$ Connecticut Sea Grant, University of Connecticut, Groton, Connecticut, USA, ${ }^{5}$ Institute of Marine Science, University of Dar es Salaam, Zanzibar, Tanzania
} 
critical role in linking ecological and market dynamics (Crona et al. 2010, Ferrol-Schulte et al. 2014, Bailey et al. 2016, Miñarro et al. 2016) trading agents are rarely accounted for by formal fisheries governance. These mostly informal sales arrangements, i.e., contracts and deals, between trading agents and VC actors can facilitate the channeling of benefits but can also hinder them. We therefore also examine contractual arrangements between VC actors as a means to understand the mechanisms behind the observed benefit flows and distribution in each case study.

As is well documented in many fishing societies, transactions in the $\mathrm{VC}$ are not purely economic but involve reciprocities and connections based on residency, kinship, and custom (Platteau 1989, Butler and Oluoch-Kosura 2006, Adhuri et al. 2016, Miñarro et al. 2016, Drury O'Neill and Crona 2017). Consequently, we also examine the broader set of relations in which the fishers and trading agents are situated to get a more holistic understanding of to whom nontrade related benefits such as food, credit, and cash flow. This analysis includes both fishing and trading (traders, buyers, retailers, etc.) as well as nontrading (auxiliary) agents, such as auctioneers, boat repairers, etc.

Gender has often also been ignored, unrepresented, or underrepresented in the SSF literature. This has resulted in women's market chain functions, and their contributions and dependencies, often remaining invisible (Kleiber et al. 2015). However, if SSF governance is to contribute to sustainable livelihoods and food security across a broad demographic, the roles of gender and market relations need to be considered as a means to unpack current benefit flows, thus a gender sensitive lens is applied in this analysis

\section{MATERIALS AND METHODS}

\section{The small-scale fisheries of Unguja and Concepcion}

\section{Sampling}

This study relies on primary data collected through structured interviews with fishers and trading agents in Unguja Island, Zanzibar, hereafter Unguja (September 2014-March 2015) and within the Iloilo Province, largely around the municipality of Concepcion in the Philippines, hereafter Concepcion (September-November 2015). These were retrospective interviews where actors were asked to recall their fishing and trading activities over the past year to discover typical fishing and trading activities within each fishing season for each location. Interviews took from 45 minutes to one hour and individuals were only interviewed once. The interview forms used to elicit data from 194 fishers and 163 trading agents in Unguja plus 280 fishers and 52 trading agents in Concepcion can be found in Appendix 1. The cases were chosen to approximate a "most similar" design often used in comparative political science. Although we cannot control for all possible system characteristics, Table 1 shows the system dimensions we aimed to control across cases. Although generalizability from two cases is limited, we believe that being explicit about these dimensions strengthens the credibility and the potential for generalizability of some of the findings in comparison with other tropical SSF. The design also allowed us to assess possible effects of the difference in market structures and market relations as a function of socio-political context (represented by country). To further facilitate the comparison, the same or comparable commodities were chosen in Unguja and
Concepcion, namely small mixed reef species, octopus (Unguja) and squid (Concepcion), using the same field instruments and sampling strategies across both countries.

Table 1. Key system dimensions controlled for in comparison across sites. Both cases, Concepcion and Unguja, are similar across all the stated dimensions thus allowing us to approximate a "most similar" design of cross-case comparison. The main attribute that differs across sites is the socio-political setting that is defined by the fact that we are studying fisheries in two different countries in South East Asia and East Africa.

System dimensions for cross-site comparison

Ecosystem Associated with tropical coral reef-mangroveseagrass ecosystems.

Fishery Type Dominated by artisanal, multigear, low-tech, multispecies small-scale fisheries.

Livelihood Communities very dependent on fishing activities for income, livelihood, and food security.

Species Landings in decline both in terms of weight and diversity of species composition (common families include Engraulidae, Siganidae, Leiognathidae, Gerreidae, Mullidae, Clupeidae).

Informal Presence of informal market institutions that institutions govern actor behavior. In our cases this refers to reciprocal agreements between fishery actors, e.g., loans, credit arrangements.

Markets

Global seafood market demands felt to some extent.

Socioeconomic context

This is the key differentiating variable because the two systems are nested in different socioeconomic and political settings (Tanzania vs Philippines).

Respondents in both countries were selected based on their involvement in the $\mathrm{VC}$ and were interviewed at landing sites, markets, ports, and at their homes on an individual basis (see Fig. 1 for a map of where interviews took place). All participants were selected based on convenience, and local gatekeepers, such as market leaders or village captains, were needed to access respondents at multiple sites. These gatekeepers were briefed in detail on the necessary respondent before selection of available actors. Detailed information on the number of respondents in each country can be found in Appendix 2. Not all nodes within the chains could be captured for logistical reasons. In the Philippines, downstream markets spread throughout Panay Island and the greater Visayan region and exporting or processing companies were difficult to capture (because they were hard to contact via phone or email and sometimes unwilling to be interviewed). In Zanzibar, downstream nodes were better captured because of the much smaller geographical area.

\section{Context}

The populations in and around both Concepcion and Unguja are heavily dependent upon the SSF for livelihoods and nutrition (Ferrer 2009, Colbert-Sangree 2012, Jeppesen and Richmond 
2016). The SSF in Unguja Island are representative of the multispecies artisanal fisheries common along the nearby Swahili coastline, with little or no commercial fleets present. It is characterized by monsoon cycles and multigear inshore based fisheries landing largely reef-associated species (e.g., Siganids, Lethrinids, Octopus) in addition to various small (e.g., Engraulids) and large (Scomberids) pelagic species (Jiddawi and Öhman 2002, DoE 2009, Office of Chief Government Statistician 2013).

Fig. 1. (a) Map of Unguja Island, Zanzibar with eight sampling sites (indicated by dots), and one on mainland Tanzania (left);

(b) Map of Panay Island (larger picture) in respect to the rest of the Philippines (inset). Study sites are centered around

Concepcion in the north, with 15 sites including markets, and central port areas on Panay Island, as well as offshore islands. Black dots in both countries represent urban sites and white dots rural sites.

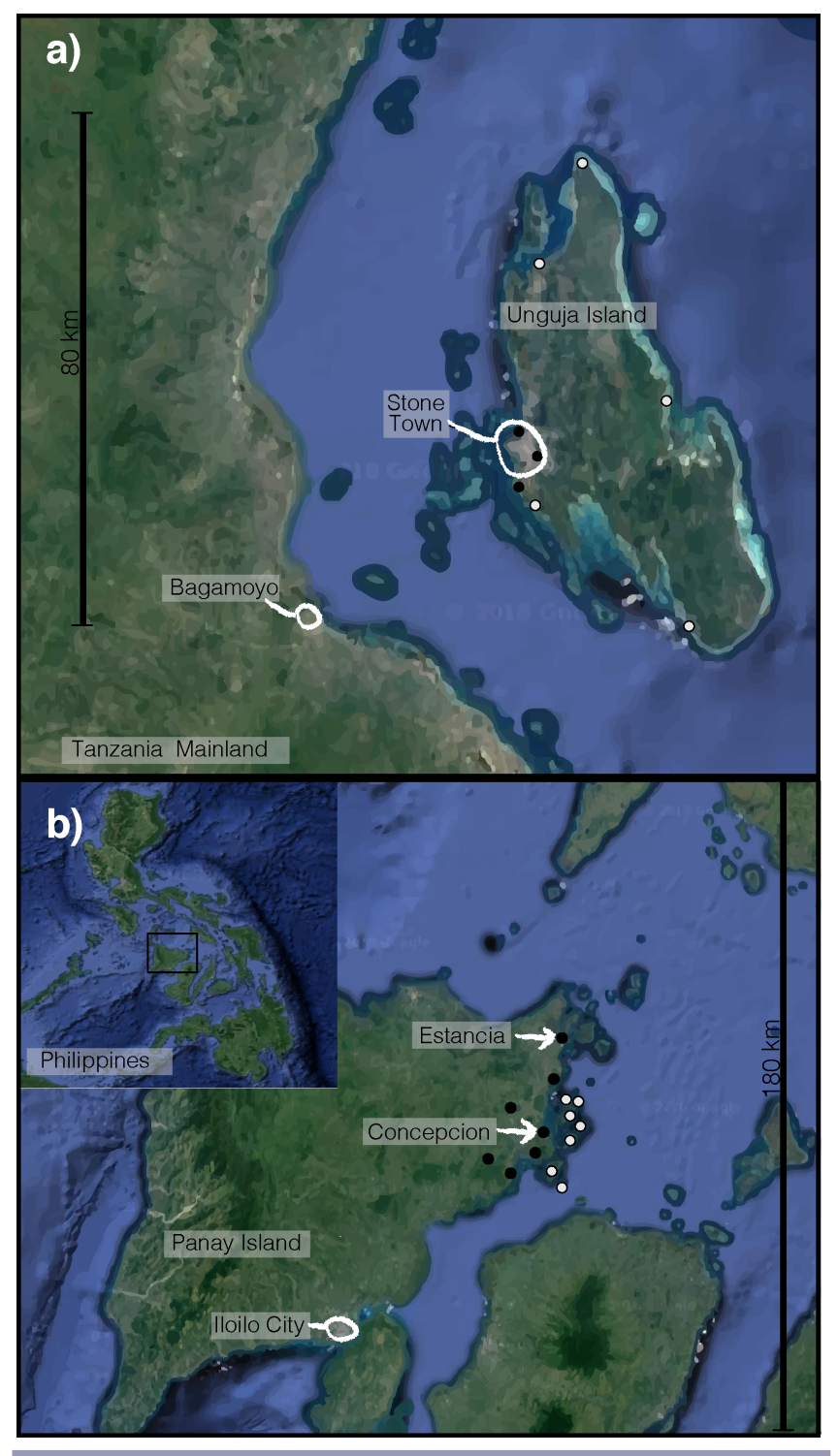

Concepcion boasts similar types of target-species. Landing sites are spread throughout 11 offshore island barangays (smallest administrative division) and various barangays and towns on the mainland island (Panay Island). The Visayan Sea, of which Concepcion is representative, is regarded as the most productive small-scale fishing ground in the Philippines, home to both smallscale and more large-scale fleets, although SSF account for twothirds of commercial landings (Ferrer 2016). As a result, Concepcion supports extensive export both to national and international markets, sourced from both small-scale and industrial fisheries (Hernando and Flores 1981). For more details on the social and political contexts of the sites, basic demographics, the main species groups targeted, market details, and marine resource management challenges see Appendix 3.

\section{Market structure}

All survey data was entered into Microsoft Excel and subsequently imported into Microsoft Access for easier handling, storage, and querying. Trading agents were characterized into different types of VC nodes. Fishers, i.e., producers, were considered as one node, but differentiated into fishing styles based on a range of factors, including gear types, vessel-use, vessel sizes, propulsion, species groups, secondary vessel use, gender and location type. To do this we adopted a simplified version of the approach elaborated by Boonstra and Hentati-Sundberg (2016). In Concepcion, the different types of trading nodes are wellestablished among the fishing and trading population and respondents were able to explain this to the interviewers. These nodes include brokers (who take commission on sales prices), buyers or collectors (based at home and can often dry), wholesalers, dryers (often women and mainly in the barangays), and retailers (have stalls in markets). In Unguja, however, trading nodes are much less distinguishable and were identified based on gender, target species (although species specific information is not reported here), buying and sales locations, processing activities, but also heavily informed by prior knowledge of the system (Thyresson et al. 2011, 2013, Fröcklin 2014, see Drury O'Neill and Crona 2017 for more details on node classification).

\section{Analysis of income and relative inequality}

Income analysis was conducted in two parts. All data was sourced from fishers' and trading agents' individual estimations because no logbooks were available. A detailed guide to all income calculations can be found in Appendix 4. The following description is a simplification of these calculations where running costs (R), average kilograms landed or traded per day $(\mathrm{Q})$ and prices per day per kilo (Sp: Sale price, Pp: Purchase price) are already standardized or made comparable. In the case of fishers instead of direct sales prices ( $\mathrm{Sp}$ ) the amount of money the fisher received at the end of a trip was used and converted to per kilo; therefore avoiding the need to take into account the sharing system between crew, vessel owners, and/or captains. Quantities and prices were averaged to get annual values for individual fishers according to biannual seasons in each location based on either trade or monsoon winds. All income data was converted to International US Dollars from Tanzanian Shilling or Philippines Peso using the appropriate purchasing power parity PPP conversion factors (C; factfish 2016). PPP refers to the number of units of a country's currency required to buy the same amount of goods and services in the domestic market as U.S. dollar would buy in the United States (factfish 2016). This conversion thus 
allows us to compare income data across the two countries. Fisher Net Income $\left(I_{f}\right)$ in International US Dollars per person per day was then calculated as:

\section{$\mathrm{I}_{\mathrm{f}}=\left[\left(\mathrm{Sp}^{*} \mathrm{Q} / \mathrm{P}\right)-\mathrm{R}\right] / \mathrm{C}$}

Trading agents net income $\left(\mathrm{I}_{\mathrm{t}}\right)$ calculations additionally included purchase prices $(\mathrm{Pp})$ :

\section{$\mathrm{I}_{\mathrm{t}}=\left\{\left[(\mathrm{Sp}-\mathrm{Pp})^{*} \mathrm{Q} / \mathrm{P}\right]-\mathrm{R}\right\} / \mathrm{C}$}

These incomes should be viewed as the value per person per day that actor is active, it represents a cumulative of all relevant species they work with in relation to the VCs of interest. The resulting income data was then examined through scatter- and boxplots and all outliers individually checked using original interview manuscripts to ensure their validity. Responses that were identified as incorrect or highly implausible were not used. Data normality was analyzed in R (Ripley 2001, version 1.0.153) with Shapiro Wilks tests, histograms, and Q-Q plots prior to further statistical analysis. Then tests for statistically significant dependencies were done between income and the variables gender and location type. For the latter, rural was defined as villages and landing sites relatively far away from central ports or markets (not walk-able and at least 30 minutes by the local transport Dala dala in Unguja), or on the island barangays off the coast of the main Panay Island, as is the case for Concepcion. Urban was defined as the central market and port environments of the cases under investigation. Incomes were tested with a nonparametric MannWhitney-Wilcoxon-test because of non-normal data.

Degree of income inequality was also examined within fishers and trading agents using Lorenz curves (graphic measure) and the corresponding Gini coefficients (Gastwirth 1972, Kakwani 1977) to assess economic benefit distributions or flows within the different fisheries. According to the FAO a Gini of 0.35 and over is high (Dillon and Hardaker 1980). To understand what factors may be driving the patterns of inequality observed (for example the hotel traders accessing high hotel prices) the differences in income between actors were then examined based on gender (because of the documented division in Zanzibar) and primary market channel targeted (tourism-, consumer-based). Furthermore, the VC mapping revealed that actor types could clearly be differentiated according to primarily urban or rural operations. This variable was therefore included in the quantitative analysis to examine if location matters in explaining within and between group income inequalities.

\section{Market conduct and assistance}

Both fishers' and trading agents' predetermined sales arrangements (an agreement, contract, or exchange, formal or informal, between two or more actors that is potentially favorable to one or more of the parties) were examined as a means to further understand and compare market conduct across the different market structures and socio-political contexts in which they operate. In the Philippines the "suki" system is a very prominent feature of most SSF. The suki system is an informal institution by which fishers market to one particular trading agent in return for favors, most commonly cash loans, or fuel. Fishers ultimately become "tied" to these trading agents, unless they repay their debt. The suki system is one form of the well-described patron-client relationship existing in many SSF (Pomeroy 1992, Pomeroy and Trinidad 1995, Carnaje 2007, Ferolin and Dunaway 2013).
Though similar relationship types exist in Zanzibar, they are not as institutionalized as the suki system in the Philippines and also have received less attention. The different nature of these two systems makes for an interesting comparison of how exactly they channel benefits and the characteristics of such flows and this is discussed below. To capture additional benefit flows (beyond economic benefits of VC participation) in the fisheries system, assistance was traced between nodes as well as within them, and between market actors and auxiliary fishery actors, e.g., transporters, auctioneers, boat repairers. Assistance was identified here as material, such as fishing gear, vessels, money, fish, food, and/or services such as processing help, transport help, assistance at sea, vessel aid etc.

\section{RESULTS}

\section{Examining market structures and relationships}

To answer the question, who is benefiting from involvement in the fisheries, research started by mapping and comparing the market structures in both sites. In Unguja the mixed reef and octopus chains amalgamated into one as the species flowed along the same pathways through the system, demanded by both the local and tourism markets. Mixed reef species and squid also flowed along similar pathways from landing in Concepcion, though dried products were much more common in the local market. There were distinct differences in market structures between the two fishery systems. From a first glance at Figure 2 (also see Figs. A5.1 and A5.2 in Appendix 5 for more detailed maps of the VCs in Concepcion and Unguja) a greater diversity of actor types emerges from the mixed reef and squid fisheries centered around Concepcion, Iloilo. Here, in contrast to Unguja, the VC incorporates brokers (those who facilitate buying and selling by taking a percentage of the selling price), large-scale wholesalers, dryers, buyers (buying and selling, no commission taken, based in their homes), large retailers or supermarkets (at the provincial level), processing companies, and additionally exporters (typically more squid and small pelagic species than the mixed reef species moving to large-scale export from the province; Fig. A5.1).

A large frequency of the initial sales were channeled through a small number of brokers $(\sim 10-15)$ in the central fish port in Concepcion and even fewer buyers at the local barangays ( $\sim-5$; 41 and $29 \%$ of respondents' sales, respectively). A contrary picture was observed in Unguja with numerous traders at all landing sites and markets (often hundreds in central sites like Malindi). The Unguja octopus and mixed reef fisheries tended to be much more local-market orientated with no major export channels out of Zanzibar identified, as opposed to export to China and Japan from Concepcion fisheries. The global tourism industry, however, is very prominent in Zanzibar; hotels, tourist restaurants, and the various connected traders are evident in the VC even at the landing sites. However only $28 \%$ of fishing and trading respondents interviewed were actually selling to either hotels, hotel traders, suppliers, or tourist restaurants, indicating quite a separation between the local and tourism markets.

Although gender is an important factor structuring the participation of women in various economic activities in Zanzibar (Fröcklin 2014, de la Torre-Castro et al. 2017, Drury O'Neill and Crona 2017), in Concepcion gender roles within the VC were more 
Fig. 2. Value chain map depicting a simplified market structure for the small-scale reef and octopus/squid fisheries in (a) Concepcion and (b) Unguja Island. Each box represents the nodes interviewed in this study and arrows the nodes to which they sell. Percentages listed for each node indicate the frequency with which a particular buyer was mentioned by all respondents of this node type. In Unguja grey lines and values indicate sales by women, and black lines and values indicate sales by men. The values listed in any one node will not necessarily add up to $100 \%$, because respondents often sell to more than one other node, and sales relations mentioned by less than $1 \%$ of respondents within the node were excluded from this figure. Note that not all nodes listed in the frequency tables were interviewed, data presented only exists for nodes represented by the larger boxes and icons. Functions that actors fulfil are described in the grey boxes in bold italics where necessary, while the processing or value added activities are listed in regular font within all boxes.
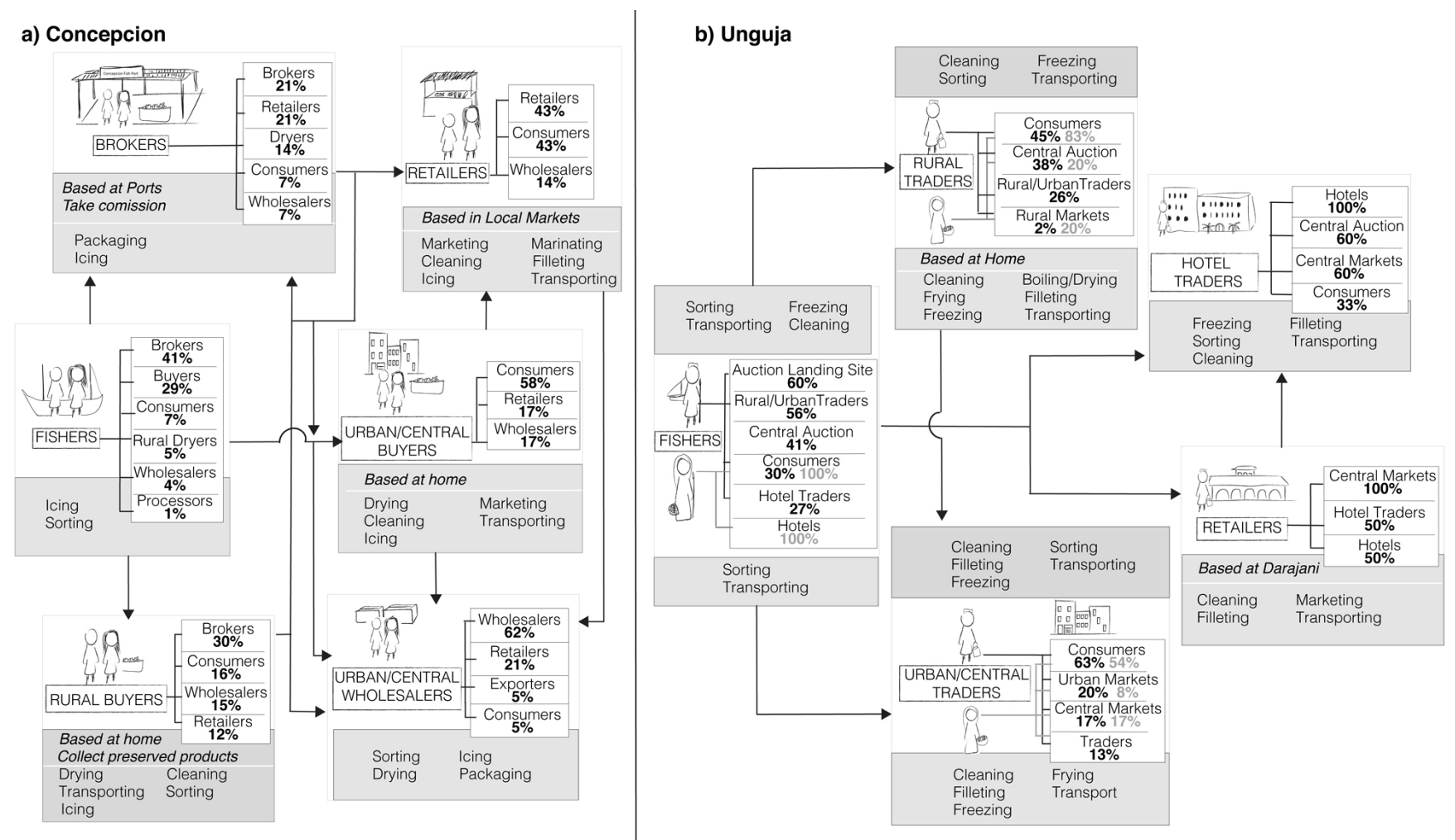

similar. From Figure 2a it is apparent that men and women participated in the same nodes. Fishing usually takes place in wifehusband, or family, crews on the vessels, unlike Unguja where women fish separately from the men and only along the shoreline by foot. During trading, women and men in Concepcion work in the same nodes, either together as husband-wife partnerships or alongside one another, selling and buying largely through the same channels. Quite distinct from this structure is the Unguja case where women largely do not work in partnerships, especially with their husbands (only $2 \%$ of respondents had a partner who was typically also a woman), and cater to local consumers only. In rural areas, women sell mainly from their houses, with weaker connections to the very central markets in Stone Town and especially with the tourist industry. However in the south of Unguja the fisherwomen interviewed were able to connect their octopus sales to nearby tourist establishments. There were no import channels identified in Concepcion for the mixed reef and squid chains because products tend to move out of Concepcion. However, in Unguja it is evident that reef fish, as well as octopus, are also being imported to supply the tourist industry and the central fish market in Stone Town from Pemba and Mafia.

\section{Understanding benefit distribution through net income}

Examination of income inequality among actors across the two systems showed a slightly higher Gini coefficient for Concepcion than in Unguja ( 0.78 vs 0.68 ) indicating that at the level of the entire market system income inequality in Concepcion was higher (Fig. 3a). When broken down into fishers and trading agents in each country, there was little difference in the fishers' income inequality across both countries (Fig. 3b). The production node in fact had a relatively low Gini indicating that there were no major differences within incomes among the different types of fishers, for both systems.

Trading agents in Concepcion and Unguja exhibited higher inequalities among respondents relative to fishers, particularly in Concepcion $(\mathrm{Gini}=0.73)$. This suggests that the driving force behind the higher inequality of the overall aggregate fishery in the Concepcion sites was primarily the larger difference in income among trading agents. Direct comparisons of trading agent and fisher incomes show that fishers in both countries, on average, earn significantly less per day than those trading (Table 2), however with a skewed distribution and various outliers (Fig. 4a). 
Fig. 3. Lorenz curves for average daily incomes per respondent, reported with Gini Coefficients (G). Panels show income inequality (a) across all market actors, across the two countries; (b) among and between fishers and trading agents; (c) across traders operating in different locations in both countries; and (d) across traders of different gender in Unguja.
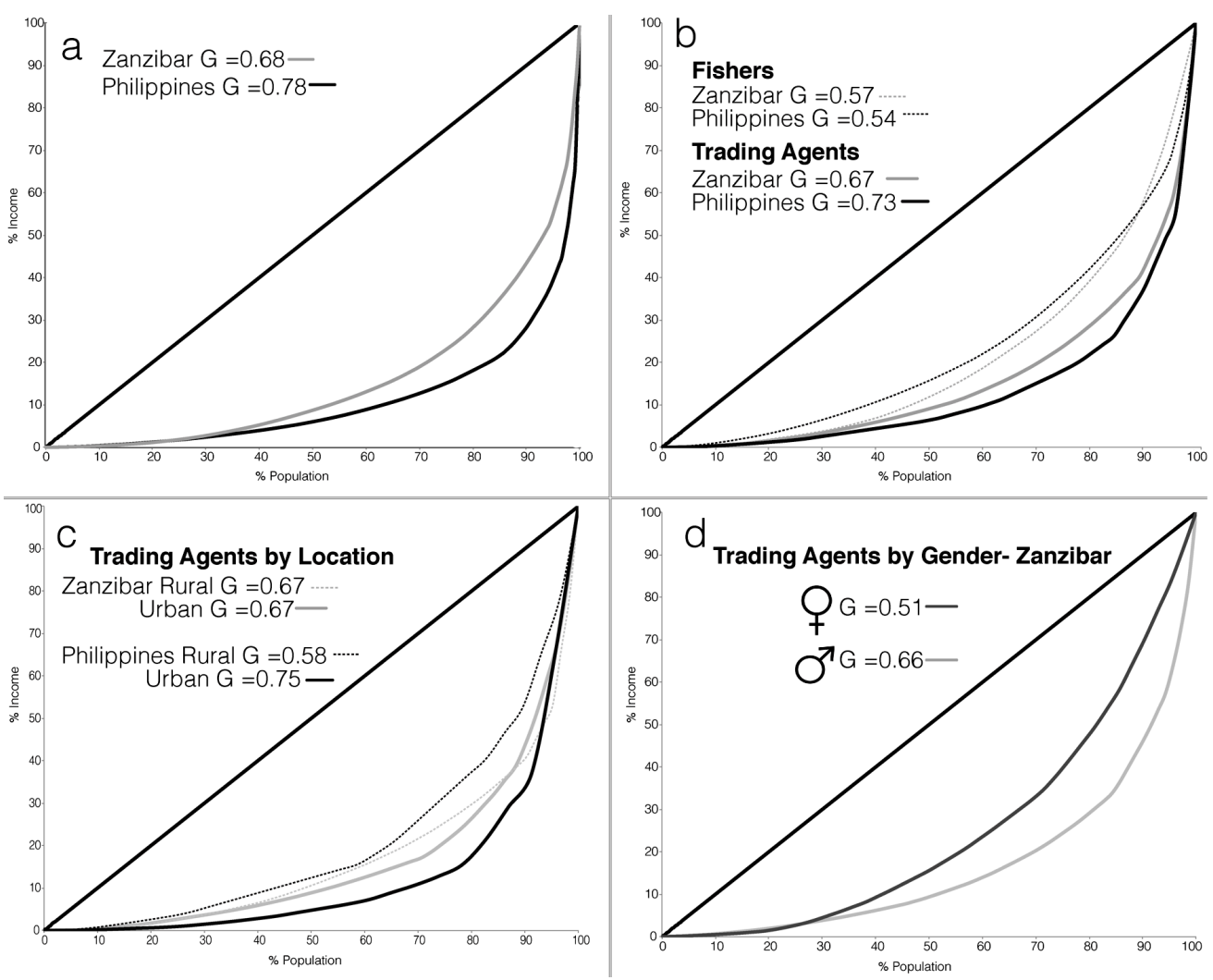

Table 2. Nonparametric Wilcoxon test results for the different income levels among various nodes or node groups. * Indicates p-value under 0.01 and $* *$ under 0.05 . The bold font indicates the group with the higher income and the regular font those with the lower income.

\begin{tabular}{llcc}
\hline \hline Location & Income Comparison & $\mathrm{n}$ & $\mathrm{P}$ values \\
\hline Concepcion & Fishers vs Trading Agents* & 239 & $5.381 \times 10^{-15}$ \\
Unguja & Fishers vs Trading Agents* & 210 & $1.142 \times 10^{-6}$ \\
Concepcion & Male vs Female Trading Agents & 52 & 0.224 \\
Unguja & Male vs Female Trading Agents* & 113 & 0.004 \\
Concepcion & Male vs Female Fishers* & 187 & 0.0005 \\
Unguja & Hotel Traders vs Nonhotel Traders** & 113 & 0.024 \\
Unguja & Hotel-Linked Fishers vs Nonhotel & 97 & 0.183 \\
& Linked Fishers & & \\
Unguja & Fishers with deals vs Fishers without & 97 & 0.671 \\
& deals & & \\
Unguja & Trading Agents with deals vs Trading & 113 & 0.005 \\
& Agents without deals* & & \\
\hline
\end{tabular}

Similarly, striking differences in the level of income inequality were found when comparing rural and urban trading agents in Concepcion, with urban agents much more unequal than rural counterparts. This difference between rural and urban operators was not noted in Unguja (Figs. 3c and 4e). However, in Unguja, female (low Gini) and male trading agents (Fig. 3d) exhibited differences in their respective levels of node inequality, with women being more equal in terms of their net income while male trading agents experienced larger inequality.

In Concepcion, where fisherwomen appeared to be able to take part equally in the $\mathrm{VC}$, their average income was nonetheless significantly lower than that of their male counterparts (see Table 2 and Fig. 4c). In Unguja, where women were fairly segregated in the $\mathrm{VC}$ and played a very specific role in terms of the value addition they performed (e.g., frying fish and selling to local consumers), there was a similarly significant difference in their average earnings compared to male traders, though men's income spanned a wider range (See Table 2 and Fig. 4b). Figure $4 b$ also shows that incomes for male trading agents in Concepcion had a large positive skew, much more so than their female counterparts.

Comparing the income distributions of actors who sell to hotels and/or to hotel traders/suppliers with those who are unlinked to tourism (in Unguja only; Fig, 4d) shows that trading agents who sell to tourism reported statistically significant higher daily average incomes than their nontourist linked counterparts, i.e., those servicing the more local market channels (Table 2), with a large positive spread. Possible drivers of this spread include the traders who supply larger quantities, between 50 and $150 \mathrm{~kg}$ per day, of high-value mixed reef species direct to hotel actors. For fishers there was no difference in incomes linked to tourism. 
Fig. 4. Box and whisker plots for income distributions across different nodes and groupings. Panels show differences in income between (a) fishers and trading in each site; (b) traders of different gender in each sites; (c) male and female fishers in Concepcion; (d) fishers and traders selling to hotels versus other markets; (e) rural and urban traders in both sites; and (f) fishers and traders with, and without, predetermined sales arrangements. Outliers are shown as small white circles. For graphical clarity outliers over US\$500 were not included in (d) and (f) while those over US\$550 were not included in (a). The line in the middle of the boxes represents the median, the end of the boxes show the upper and lower quartiles, the lines out from the boxes show the highest and lowest values.

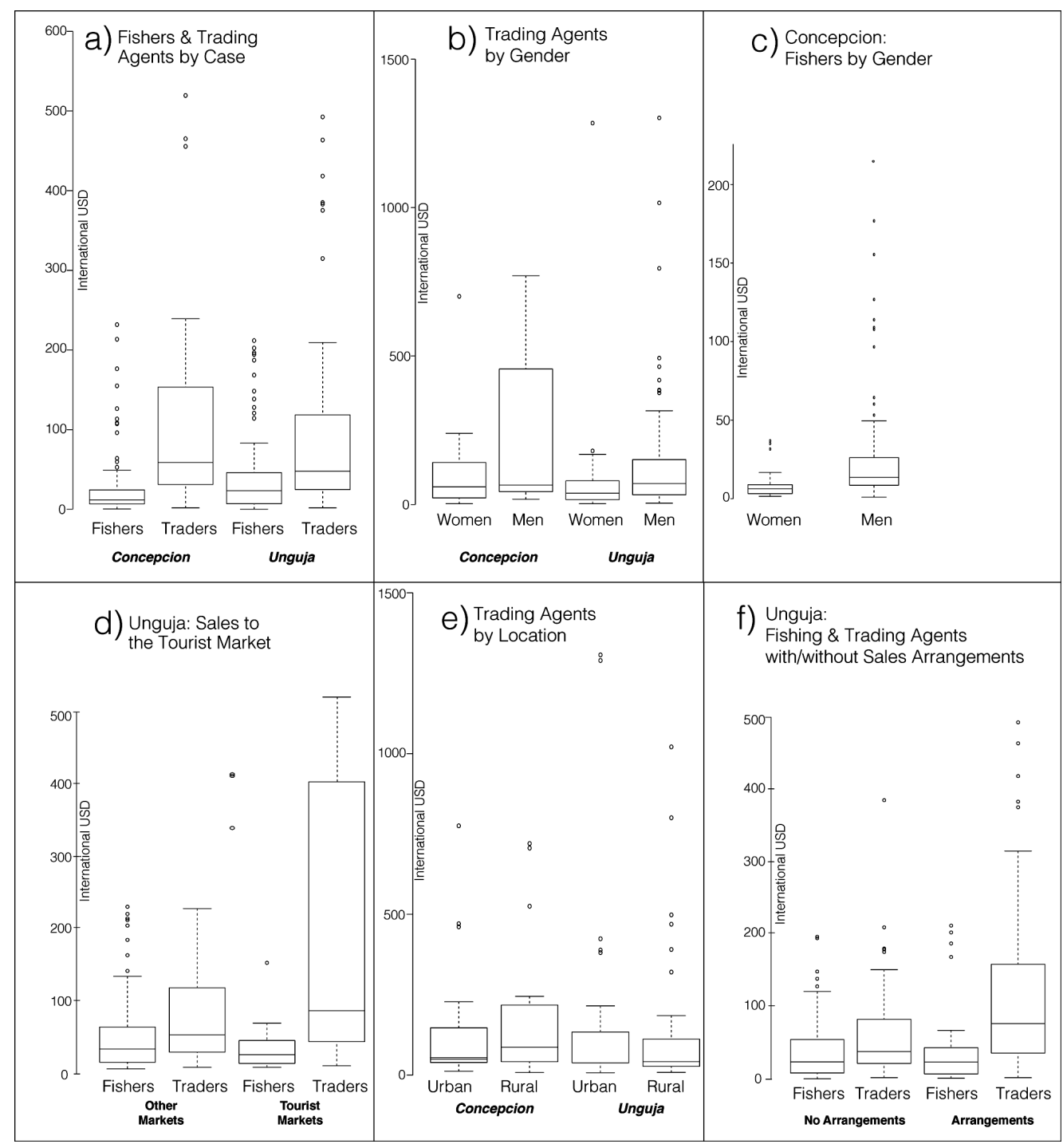

Examining Unguja fishers' and traders' net incomes, with or without sales arrangements, shows that for the latter making such arrangements constitutes a significantly higher income than their counterparts without any (Figure 4f, Table 2). This was an unexpected result because trading agents with arrangements were generally assumed to have lower flexibility in their sales choices, lower bargaining power, and less access to price increases or new markets (Eaton et al. 2007). These traders stated they made arrangements to sell largely as a result of customers seeking and placing orders for seafood with them, either from random meetings or sometimes through previous family and friend connections. For fishers there was no difference in earnings for those with predetermined sales arrangements or not (Fig. 4f). In Concepcion nearly all the actors sell through the suki system and similar comparison is therefore not relevant.

Finally data was unpacked at the individual-actor level to better understand economic benefit distribution on the ground. In Unguja the fishers with above average daily net income values were those catching mixed reef and octopus species with more 
traditional gear (hand lines, traps, and spears) using small canoe/ outrigger vessels (nonmotorized) or foot fishing. In Concepcion fishers targeting multiple species groups (squid, mixed reef, and small pelagics) with most common traps or bottom set gill nets from large $(>7 \mathrm{~m})$ mechanized vessels were those with higher than average income values. In Unguja, male and female trading agents who buy in the rural landing sites, use freezers or cool boxes, and transport their products into the central fish market tended to have above average incomes. In Concepcion buyers, regardless of genders and across both rural and urban settings, were most frequently in the above average income group. Additionally wholesalers linked to export outside of Concepcion reported higher than average daily incomes.

\section{Investigating predetermined sales arrangements}

Because patron-client type relationships tended to be frequently observed in SSF, examining the nature of these predetermined arrangements, and their prevalence, is important for understanding how, if at all, they affect the benefits that actors capture as a result of their market place participation. Regardless of the degree of formalization surrounding such market-actor relations, they have the potential to both affect net income, as well as be a source of additional benefits.

The large majority (see Fig. 5) of Concepcion fishers' reported sales taking place through predetermined arrangements (over $90 \%$ of respondents), the majority of their contracts being with the brokers ( $41 \%$ of fishing respondents) and buyers (29\%). In Unguja, however, the reported market conduct by fishers was distinctly different, buying and selling is much less predetermined, more often through on-the-spot transactions, and/or through auctions, the latter of which do not exist in the Concepcion. When Zanzibar fishers do make arrangements, it was commonly with downstream local traders, the tourist industry, or local consumers.

When fisher participants were asked about the flexibility of these arrangements, if they could stop them or not, half of Concepcion fishers felt they could not, mainly as a result of the loans they have with the trading agent in question $(34.6 \%$ of those who felt they could not stop). Additionally, almost $20 \%$ of these fishers agreed that a "sense or debt of gratitude" toward the trading agent meant they could not stop, i.e., the fisher owes them because they provided them with help. Remaining responses brought up factors such as distance (i.e., the physical closeness of the available trading agents, particularly relevant for fishers based on the offshore islands), "suki support" (the financial and material support fishers can receive from a linked or predetermined trading agent), the fact the trading actor was their relative and the prices offered were relatively good. In Unguja, a similar theme appeared with regard to the social status or obligation of the fisher if they were to end an arrangement ( $42 \%$ of fishers could not end the arrangement). The majority were concerned that terminating a relationship would create misunderstandings with their customers (generally traders). However, they did not report being tied to specific traders through economic debt like in Concepcion, but instead cited the fact they might not get any more help from the customer, and as such would suffer a profit loss or a loss in their overall business.
Fig. 5. Bar charts showing the frequency of sales arrangements between (a) fishers and their buyers, and (b) traders and their buyers in Unguja (darker grey) and Concepcion (lighter grey). Percentages indicate the proportion of arrangements with each type of node (x-axis). The bars represent the $\%$ frequency of interview respondents' answers.

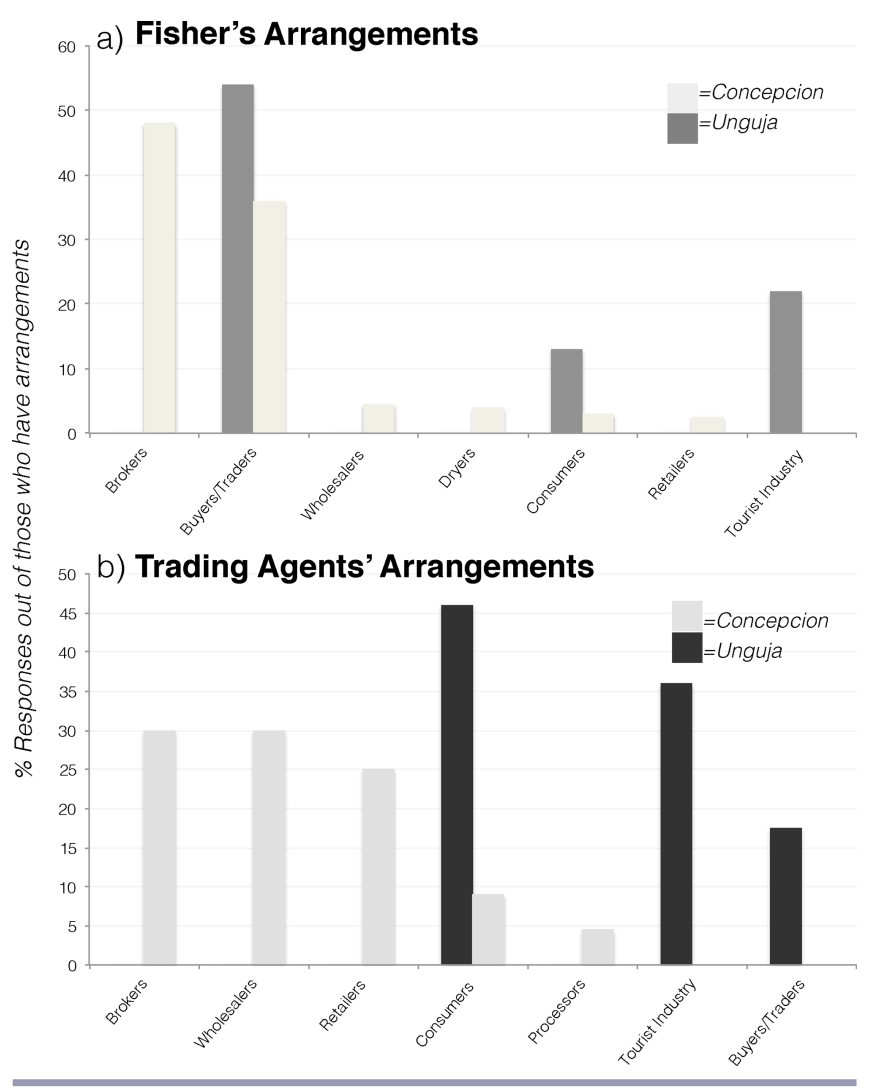

Moving downstream, trading agents marketed almost exclusively through suki arrangements in Concepcion ( $\sim 97 \%)$, largely to brokers and buyers further downstream rather than to consumers locally. These sales arrangements appeared equally frequent across male and female trading agents in Concepcion $(100 \%$ of men and $93 \%$ of women). The opposite is true in Unguja where less than half of the traders sell to a predetermined actor, and for those who do, consumers are the repeated customer-type ( $46 \%$ of their arrangements). In terms of gender, Unguja male traders more frequently had arrangements than their female counterparts ( $54 \%$ of men versus only $15 \%$ of women).

When asked about their ability to stop arrangements, trading agents in Concepcion responded that they could not because they lacked other outlets to sell their fish to or that they already had a base of regular customers. The frequency of being tied in arrangements (approximately half of respondents) was similar among trading and fishing respondents in Concepcion (only a $1.4 \%$ difference). In Unguja $25 \%$ more traders than fishers, $67 \%$ in total, reported inability to stop their arrangements, citing the same reasons as the fishers (social obligation and concerns about misunderstandings). 
Fig. 6. Assistance exchange network in Concepcion (a) and Unguja (b). This figure schematically illustrates the networks through which assistance, in the form of material, i.e., fishing gear, vessels, money, fish, and food, and/ or services, processing help, transport help, assistance at sea, vessel aid, etc., were exchanged between nodes. Dashed lines represent flows of assistance received or provided by women, while bold lines represent male exchanges. Double line arrows represents both genders. Fundi refers to the men who fix boats and nets and other fishing gear or equipment.

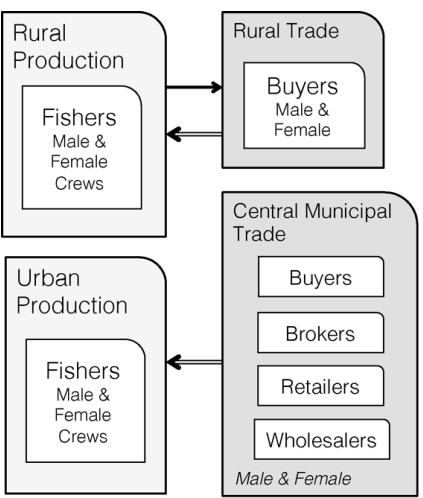

a) Concepcion

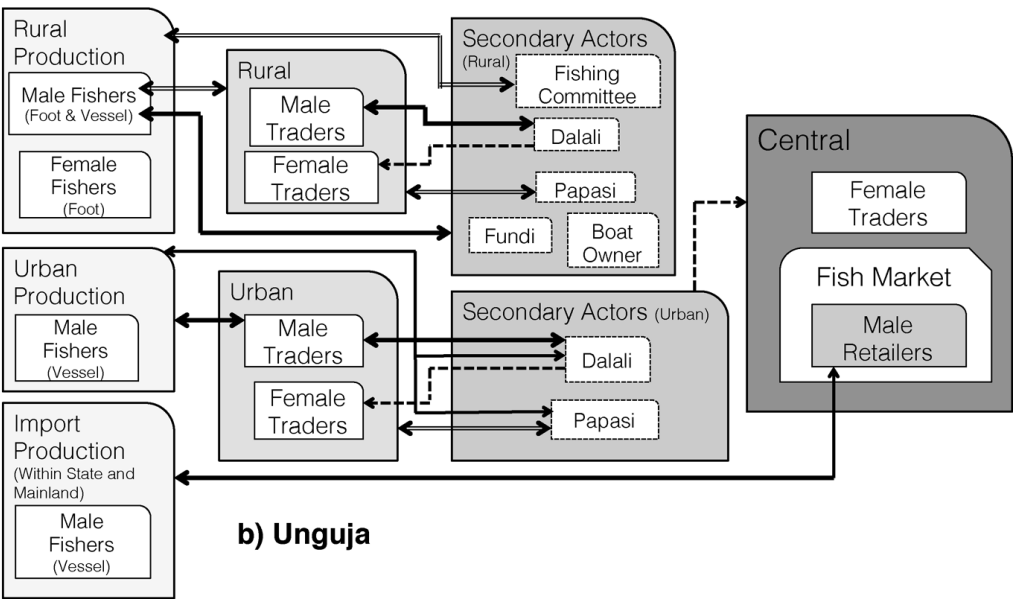

\section{Beyond sales: benefit flows through assistance}

Assistance in this study entails the frequent exchange of material or service provision between actors in different $\mathrm{VC}$ nodes and is used to capture the informal noneconomic benefit exchanges that take place among market actors. These types of exchanges provide benefits above and beyond the net income derived from the trade.

When compared to Unguja, respondents in Concepcion took part in these informal assistance exchanges with a less diverse array of market actors and in a less mutual way (Fig. 6). Trading agents in Concepcion frequently provided support (as defined here) but did not receive it back (Fig. 6a). Additionally, they responded that they only provide or receive help to or from fishers or trading agents within the market, i.e., no auxiliary actors were identified, with the help largely flowing from the trading agents to the fishers.

This latter type of informal exchange was much more common between actors in Unguja (Fig. 6b). In mapping assistance flows, various secondary or auxiliary actors also appeared, for example, what respondents called Papasi, also known as Msaidizi (Narriman Jiddawi 2017, personal communication). These are younger male helpers around landing sites and markets who carry and/or assist fishers and trading agents in processing. Other actors such as the Dalali (auctioneer), the Fishing Committees, the net/ vessel fixers, and the boat owners were also involved in the reciprocities.

Within-node assistance was quite frequently cited across both cases. In Concepcion, fishers predominately helped each other by securing vessels on the shore at low tide, getting tows at sea, borrowing gear, and providing bait. Fishers also stated that they must repay this assistance by offering it themselves to their colleagues. In Unguja fishers exchanged money, fish for home consumption, gear, and assistance at sea (towing, offering fuel, helping fix gear/engine) with each other without requiring payback. Both Concepcion and Unguja trading respondents frequently provided each other with financial assistance. In Unguja, however, there are additional exchanges of fish for home, products to sell, and help with selling.

A closer look at the help between fishers and trading agents in Concepcion showed exchanges were based more around finance and all respondents were obliged to pay back through their sales or via cash repayments or both $(100 \%$; see Table A6.1 in Appendix 6 for a breakdown of the type of help going between fishers and trading agents in both countries). Around $40 \%$ of trading agents who provided fishers with frequent support required delivery of their catch directly as a means of payback. This latter form of payback is linked to the suki system, whereby trading agents have fishers tied to them through the provision of loans, vessels, and/ or gear, and fishers become their suki as they, in return, continuously sell to them.

In Unguja more fishers provided help than they received, often with no payback mechanisms in place. In fact, $67 \%$ of trading agents who received help from fishers did not pay back. Fishers, on the other hand, were required to pay back more often than trading agents, as 30\% said they must repay the loans with cash when they have it.

Assistance networks between market actors across the two countries were thus starkly different. Concepcion exhibited a more limited web of support, both in terms of actors involved and reciprocity, with a more financial focus, whereas the Unguja fisheries assistance network was wider reaching, diverse in support-types, and less hierarchical or dependent on VC position.

\section{DISCUSSION}

Summarizing the findings, the Unguja market place is characterized by a large number of trading agents and on-thespot transaction types, local consumers play an important role in market dynamics, and are frequently involved in contracts 
through predetermined arrangements. In contrast, the Concepcion system is more highly contractualized (cf. Riisgaard et al. 2008), where fishers and trading agents are predominately tied to each other via these arrangements, and products are directed toward wholesale and retail. In addition, there is a higher concentration of trading agents within the market. Economic exchanges revolve more around provision of financial capital, although in both systems social standing and obligations play a role in determining market structures. Below we discuss what these general features of each system mean for the participation of various actors in the seafood trade and how these observed structures affect benefit flows and distribution.

\section{Seafood market structure and participation}

Market structures are quite different across the two case regions, in terms of the actors included, the roles they play in the VC, and their relative numbers as well as end markets. A key finding that emerges from this analysis is the different ways in which gender affects structure and functioning of the Unguja and Concepcion market places, while recognizing intersectionality, i.e., that other factors like ethnicity, poverty, or geography may also be important, potentially more so than gender (Kabeer 2003, Bryson 2016). The roles of men and women are deeply entrenched in local gender identities linked to the broader socio-cultural context (FAO 2017), thus it is no surprise to see how men and women participate differently in the two different settings. However the reverse is also possible, where VC governance influences the gender relations, e.g., marketing companies adopting genderbased strategies in their campaigns to sell high value goods (Barrientos 2001).

In both study locations women have typically been viewed as secondary or minor participants in SSF VCs, quite frequently by external actors like officials and researchers (Siason 2000, Fröcklin 2014, Kleiber 2014, Pastor 2016, Pavo 2016, Williams 2016, de la Torre-Castro et al. 2017). This is at odds with the fact that in various parts of the Philippines women have been previously documented as large-scale financers, active fishers at sea, traders, processors, and gear fixers (Siason 2000, Suntornratana 2003, Kleiber 2014, Pastor 2016, Pavo 2016). This study, like Pavo (2016), presents a different picture of women's experience in fishery VCs, in which they do not necessarily fill conceived VC "spaces," i.e., as conceived by planners, designers, or scientists. Conceived space is referred to here as the socially constructed and conceptualized space in which social or political practices play out (Lefebvre and Nicholson-Smith 1991). Nevertheless, at the production level, women who do partake in fishing end up with relatively less economic benefits. Validation of results by the studied communities in November 2017 confirmed this as unsurprising for Concepcion fisherwomen. As explained to the authors, rather than what they feel are lived cultural constraints or social norms, they spend less time out fishing because of the harder physical labor demanded by this activity and necessary domestic duties, thus they can end up with less daily income. Data on hours spent fishing per day from structured interviews supports this argument.

Gender appears to be a strong organizational category within seafood VCs on the Swahili Coastline (see Brugere and Bodil 2014, Fröcklin 2014, Matsue et al. 2014, Lentisco and Lee 2015, Wamukota 2015, Wosu 2017), often defining women's activities, for example, their interactions with the tourist industry (La Cour Madsen 2003, Demovic 2016). However, deviations from the often dominant narrative presented by gender-related fishery studies, i.e., women as secondary, marginal, and often weaker players (Tindall and Holvoet 2008, Westerman and Benbow 2013, Brugere and Bodil 2014, Fröcklin 2014) can be seen in Unguja. In the south of the island five fisherwomen have linked directly to the global market whilst those traders in the sample that have above average incomes included females not trading in a conceived space (not where they are perceived to be), i.e., freezing/icing products from rural areas and transporting them for sale in the central market. These counter narratives are important because they highlight the potential of female actors to adopt more traditionally male economic niches in changing market environments, suggested by McClanahan and Abunge (2017) as a possible requirement for sustainable fisheries.

There is evidence in both country cases that women are gaining ground, e.g., in positions and numbers, in the SSF market environment, however, the question remains if these examples are simply cracks in the dominant narrative or future trends in VC participation for women. In East Africa there are indications that men have begun to encroach into hitherto distinctly female arenas. Porter et al. (2008) found that women who harvest or trade shellfish, sea cucumbers, seaweed, octopus, or jellyfish often get displaced by men when these products become global commodities. Nevertheless the stories of women's participation in fisheries that are increasingly connected to global seafood trade are multifaceted and shaped not just by their gender but also by factors such as household assets, size and composition, education and skills (Tindall and Holvoet 2008). Gender must be placed in the broader social processes at play around the fisheries, rather than being singled out, if researchers are to better understand women's long-term VC positions (Wosu 2017).

\section{Informal institutional arrangements and benefit flows}

Although a significant amount is known about the nature of patron-client relations, we attempted to ask how the presence or not of such arrangements affects benefit distribution. Interestingly it appears they do not play any major role for income distribution within the production node in Zanzibar. Fishers tied to a trader do not appear to be any worse off, in terms of daily income, then their counterparts who sell more ad hoc. This contradicts findings from numerous SSF studies of buyer-client fisher relationships, where buyers have been observed influencing fishers to accept lower prices as a result of unequal bargaining power and/or indebtedness (Platteau and Abraham 1987, Johnson 2010, Nurdin and Grydehøj 2014).

The opposite is true among trading agents. Those who engage in predetermined sales arrangements with their clients receive relatively higher economic benefits. This could be due to the commonality of these arrangements with the tourist industry, which demands high value and volumes of products. A majority of these arrangements are also with the local market and, relative to products sold outside arrangements, local prearranged customers demand higher volumes. Handling larger quantities of fresh or iced fish requires some type of coordination if traders are to sell unspoiled products efficiently. In Unguja vertical contractualization (see Riisgaard et al. 2010) has, in some way, played a role in enabling trading actors to deal with larger quantities, potentially resulting in higher incomes. 
Although quantitative analysis shows that fishers receive no clear economic benefit from making predetermined sale arrangements, also seen by Miñarro et al. (2016), they are able to access a range of other benefits through them. These benefits appear to be exchanged in distinct ways between trading agents and fishers in the two cases. In Unguja, providing help to fishers, or vice versa, does not necessarily imply a counter obligation; much of the exchanges can be regarded as gifts according to respondents suggesting that our surveys identified a generalized type of reciprocity (Thomas and Worrall 2000). In Concepcion the assistance between fishers and trading agents is largely loans, tightly linked to the suki system, with a more complete reckoning of counter obligation. The generalized reciprocity observed in Unguja can be more effective as an insurance mechanism to the individual or households in the short term because one can access food or cash off a wide range of actors in the fishery. However, Thomas and Worrall (2000) argue that by adding a clear repayment aspect to loans, arrangements that could breakdown because of lack of benefit compensation to the giver can be made more stable, and thus more beneficial, in the long term. On the other hand, data shows that prearranged transactions often create inflexible structures, observed through the inability of respondents to end these arrangements. Similar reasons for not being able to discontinue sales arrangements emerged throughout both case studies where feelings of social obligations mixed with economic imperatives appear to underlie arrangements. Indeed, within these interlinked systems of personal transactions the possible discovery of dishonesty, unwillingness, or avoidance by an agent in one transaction is made too costly for him or her in terms of the spillover effects threatening other transactions and the general loss of goodwill within these relatively small rural villages or towns (Platteau and Abraham 1987, Adhuri et al. 2016).

Ultimately, this study adds more evidence to the growing body of work that shows the complex web of social and economic relations in which SSF market actors are embedded. Aspects of the reciprocal arrangements discussed above may be important as social insurance mechanisms for individuals, while at the same time creating inflexible structures that may perpetuate unsustainable resource extraction (Crona et al. 2010, FerrolSchulte et al. 2014, Nurdin and Grydehøj 2014, Kininmonth et al. 2016, Miñarro et al. 2016, ). However, the main argument is that across different socio-political settings, the relations do appear to play a critical role in structuring the market place and conduct, yet they are generally never explicitly considered in fisheries related policy or governance.

\section{Income disparity and distribution}

Remarkably few studies exist in which to situate our findings. Little published work exists assessing income equality and the distributional aspects of fisheries profits within SSF. One Kenyan example (Wamukota et al. 2014) witnessed a relatively high Gini in the Kenyan octopus fishery and attributed this to the small number of agents controlling the procurement and marketing of octopus on behalf of local processing plants, who often provide fishers with gear and employment directly on their behalf. The slightly higher inequality observed at the aggregate level in Concepcion is probably due to a large proportion of sales moving through a small number of established brokers (in fish ports) and buyers (in island barangays), i.e., market concentration, who employ the suki system to engage fishers (a relationship type frequently less pervasive in Unguja), thus impacting income equality through prices and indebtedness (Pomeroy and Trinidad 1995, Carnaje 2007, Ferolin and Dunaway 2013). The urban Gini coefficient confirms the high inequality among trading agents' incomes and potential oligopolistic market conditions in urban mainland. This concentration in Concepcion is not unique within the Philippines, and has been previously seen in fishery VCs in Manila and Leyte (Torres et al. 1987, Pomeroy 1990). Although the Concepcion VC structure supports, through participation, a much more equal gender balance, income disparity aggregately is higher than that of the highly unequal trading system (in terms of gender participation) in Unguja.

When data is disaggregated to fishers and trading agents, the similarly low Gini coefficients among fishers in both cases indicate that although market structures and institutional arrangements differ in both contexts this does not appear to affect within-node benefit equities. Furthermore, the fact that fishers in both countries report significantly lower incomes than the trading agents reiterates the general findings in SSF case studies over the past decade (Bjørndal et al. 2015).

The integration of SSF economies into global seafood markets is increasing rapidly yet it is still unclear how actors on the ground benefit monetarily, or by other means (see Béné et al. $2010 \mathrm{~b}$ for the debate linked to poverty alleviation). Global markets manifest themselves in different ways in Unguja and Concepcion. The commercialization of the Filipino fisheries since the early 2000s has likely fueled the movement of most seafood products away from Concepcion's landing sites to inland, national, and international markets on upgraded bridges, roads, and infrastructure. Whereas on the other side of the world, tourism markets that increasingly contribute to national GDP are directing products from local trade to hotels and restaurants (Gössling 2001, La Cour Madsen 2003, Thyresson et al. 2013).

Tourism is viewed, from a neoliberalist point of view, as a positive thing because if well-managed it can support local development while transferring capital from the developed to the developing world (Gössling 2001, 2003). However the changes that tourism development creates are complex and consequences are often not visible in the short term (Gössling 2001, 2003). In terms of local VC actors, a few traders ( $28 \%$ of the sample) in Unguja benefit financially on a short time scale because they earn higher daily net incomes than traders not connected to this lucrative market. Whether always understood by local respondents or not, global market integration, either through consumer exports and/or tourism development, is on the agenda in both the Philippines and Zanzibar. Global seafood interests in the form of Asianfunded (Japan and South Korea) fish port complexes are due to be built in both study sites commencing 2018 (The East African 2012, SunStar Iloilo 2017). There are plans for Concepcion port to double in size creating more space for fishers, brokers, and fish trading. These types of global incentives, which in these cases are linked to major seafood importers (Japan and South Korea are among the top 10 countries worldwide, https://comtrade.un.org/) are hard for local less-powerful operators to withstand. Incentives can stimulate more actors (large and small) to enter the VC of already badly managed, declining fisheries (DoE Department of the Environment 2009, Ferrer 2016). 
The year 2018 marks major development in the fishery VCs of Unguja and Concepcion as the market and port expansions get underway. Neoclassical economic theory suggests global market integration is a viable strategy to reduce poverty. However, it is difficult to understand how exactly fishers and trading agents in the current cases can access the growth in wealth projected to emerge from this integration. How will local Zanzibari women traders access the economic benefits from tourism if unable to afford fish species demanded by the hotels? How will Filipino fishers be able to keep investing in modern fishing gear to increase extraction for growing demands without further reliance on their buyers for finance, and without further pressuring already stretched natural resources? Local fisheries management in both cases needs to extend management up the VC to understand how international market initiatives impact the local trading system and in particular marine ecosystem exploitation. These types of results call attention to the need for the fisheries-poverty-trade debate to incorporate more case-orientated examples of benefit distribution on the ground.

Responses to this article can be read online at: http://www.ecologyandsociety.org/issues/responses. php/10331

\begin{abstract}
Acknowledgments:
Above all, the authors would like to express a genuine and sincere thank you to the communities of Unguja Island Zanzibar and Concepcion, Iloilo. Without their willingness and patience with us there would be no research. Big, big thanks to Joey Pedrajas, Ramadhan Rashid Hassan, Matilda Thyresson, Jinky Hopanda, Mkanga the teacher, Mohammed S. Jiddawi, Dave, Ricky, and the Junbees Team (including the late Chloe). We acknowledge the Zanzibar Institute of Marine Sciences (University of Dar es Salaam) and the University of the Philippines Visayas. This work was made possible through the generous contribution of SIDA (The Swedish International Development Cooperation Agency) through Grant number 1425704, by MISTRA funding to the Stockholm Resilience Center, and funding to the Global Economic Dynamics and the Biosphere program by the Erling-Persson Foundation.
\end{abstract}

\section{LITERATURE CITED}

Adhuri, D. S., L. Rachmawati, H. Sofyanto, and N. HamiltonHart. 2016. Green market for small people: markets and opportunities for upgrading in small-scale fisheries in Indonesia. Marine Policy 63:198-205. http://dx.doi.org/10.1016/j.marpol.2015.03.021

Bailey, M., S. Bush, P. Oosterveer, and L. Larastiti. 2016. Fishers, fair trade, and finding middle ground. Fisheries Research 182:59-68. http://dx.doi.org/10.1016/j.fishres.2015.11.027

Barrientos, S. 2001. Gender, flexibility and global value chains. IDS Bulletin 32(3):83-93. http://dx.doi.org/10.1111/j.1759-5436.2001. mp32003009.x

Béné, C. 2003. When fishery rhymes with poverty: a first step beyond the old paradigm on poverty in small-scale fisheries. World Development 31(6):949-975. http://dx.doi.org/10.1016/S0305-750X (03)00045-7
Béné, C., E. Bennett, and A. Neiland. 2004. The challenge of managing small-scale fisheries with reference to poverty alleviation. Pages 83-102 in A. E. Neiland and C. Béné, editors. Poverty and small-scale fisheries in West Africa. Springer, Dordrecht, The Netherlands. http://dx.doi.org/10.1007/978-94-017-2736-5_6

Béné, C., B. Hersoug, and E. H. Allison. 2010a. Not by rent alone: analysing the pro-poor functions of small-scale fisheries in developing countries. Development Policy Review 28(3):325-358. http://dx.doi.org/10.1111/j.1467-7679.2010.00486.x

Béné, C., R. Lawton, and E. H. Allison. 2010b. "Trade matters in the fight Against poverty": narratives, perceptions, and (lack of) evidence in the case of fish trade in Africa. World Development 38(7):933-954. http://dx.doi.org/10.1016/j.worlddev.2009.12.010

Béné, C., G. Macfadyen, and E. H. Allison. 2007. Increasing the contribution of small-scale fisheries to poverty alleviation and food security. FAO Fisheries Technical Paper. No. 481. Food and Agriculture Organization, Rome, Italy.

Bjørndal, T., A. Child, A. Lem, and M. M. Dey. 2015. Value chain dynamics and the small-scale sector: a summary of findings and policy recommendations for fisheries and aquaculture trade. Aquaculture Economics \& Management 19(1):148-173. http://dx. doi.org/10.1080/13657305.2015.994241

Boonstra, W. J., and J. Hentati-Sundberg. 2016. Classifying fishers' behaviour. An invitation to fishing styles. Fish and Fisheries 17(1):78-100. http://dx.doi.org/10.1111/faf.12092

Brugere, C., and M. Bodil. 2014. Study of fisheries and aquaculture value chains in Mozambique: how to reduce gender discrimination in the fisheries and aquaculture sectors. Norwegian Agency for Development Cooperation NORAD, Norway, Oslo, Norway.

Bryson, V. 2016. Feminist political theory. Palgrave Macmillan, London, UK.

Butler, C. D., and W. Oluoch-Kosura. 2006. Linking future ecosystem services and future human well-being. Ecology and Society 11(1):30. http://dx.doi.org/10.5751/ES-01602-110130

Carnaje, G. P. 2007. Contractual arrangements in Philippine fisheries. Discussion Paper Series No. 2007-22. Philippine Institute for Development Studies, Quezon City, The Philippines.

Colbert-Sangree, N. 2012. The state of artisanal fisheries in southern Unguja: governance, conservation and community. Independent Study Project (ISP) Collection. [online] URL: $\underline{\text { http:// }}$ digitalcollections. sit.edu/isp collection/1279

Crona, B., M. Nyström, C. Folke, and N. Jiddawi. 2010. Middlemen, a critical social-ecological link in coastal communities of Kenya and Zanzibar. Marine Policy 34 (4):761-771. http://dx.doi.org/10.1016/j.marpol.2010.01.023

de la Torre-Castro, M., S. Fröcklin, S. Börjesson, J. Okupnik, and N. S. Jiddawi. 2017. Gender analysis for better coastal management - increasing our understanding of social-ecological seascapes. Marine Policy 83:62-74. http://dx.doi.org/10.1016/j. marpol.2017.05.015

Demovic, A. R. 2016. Where are the women when the tourists arrive?: bodies, space, and Islamic femininity in Rural Zanzibar. 
Journal of Africana Religions 4(1):1-27. http://dx.doi.org/10.5325/ jafrireli.4.1.0001

Dillon, J. L., and J. B. Hardaker. 1980. Farm management research for small farmer development. Food and Agriculture Organization, Rome, Italy.

Department of the Environment (DoE). 2009. The status of Zanzibar coastal resources: towards the development of integrated coastal management strategies and action plan. DoE, Zanzibar.

Drury O'Neill, E., and B. Crona. 2017. Assistance networks in seafood trade: a means to assess benefit distribution in small-scale fisheries. Marine Policy 78:196-205. http://dx.doi.org/10.1016/j. marpol.2017.01.025

Eaton, D., G. Meijerink, J. Bijman, and J. Belt. 2007. Analysing the role of institutional arrangements: vegetable value chains in East Africa. European Association of Agricultural Economists, Wageningen, The Netherlands.

factfish. 2016. factfish PPP conversion factor, GDP world statistics and data. factfish, Munich, Germany. [online] URL: http://www. factfish.com/statistic/ppp $\% 20$ conversion $\% 20$ factor $\% 2 \mathrm{C} \% 20 \mathrm{gdp}$

Ferolin, M. C., and W. A. Dunaway. 2013. Globalized fisheries, depeasantization and debt bondage in Philippine seafood exporting. International Journal of Humanities and Social Sciences 3(13):45-54.

Ferrer, A. J. G. 2009. Evaluation of fisheries management options for the Visayan Sea, Philippines: the case of northern Iloilo. EEPSEA Research Report, Economy and Environment Program for Southeast Asia, Ho Chi Minh City, Vietnam.

Ferrer, A. J. G. 2016. Fisheries management options for Visayan Sea, Philippines: the case of northern Iloilo. Pages 287-309 in N. Olewiler, H. A. Francisco, and A. J. G. Ferrer, editors. Marine and coastal ecosystem valuation, institutions, and policy in Southeast Asia. Springer, Singapore. http://dx.doi.org/10.1007/978-981-10-0141-3 14

Ferrol-Schulte, D., S. C. A. Ferse, and M. Glaser. 2014. Patronclient relationships, livelihoods and natural resource management in tropical coastal communities. Ocean \& Coastal Management 100:63-73. http://dx.doi.org/10.1016/j.ocecoaman.2014.07.016

Food and Agriculture Organization (FAO). 2017. Towards genderequitable small-scale fisheries governance and development. FAO, Rome, Italy.

Fröcklin, S. 2014. Women in the seascape: gender, livelihoods and management of coastal and marine resources in Zanzibar, East Africa. Dissertation. Stockholm University, Stockholm, Sweden.

Gastwirth, J. L. 1972. The estimation of the Lorenz curve and Gini index. Review of Economics and Statistics 54:306-316. http:// dx.doi.org/10.2307/1937992

Gössling, S. 2001. Tourism, economic transition and ecosystem degradation: interacting processes in a Tanzanian coastal community. Tourism Geographies 3(4):430-453. http://dx.doi. org/10.1080/146166800110070504

Gössling, S. 2003. Market integration and ecosystem degradation: Is sustainable tourism development in rural communities a contradiction in terms? Environment, Development and Sustainability 5(3-4):383-400. http://dx.doi.org/10.1023/A:1025777029741
Hernando, A. M., and E. E. C. Flores. 1981. The Philippines squid fishery: a review. Marine Fisheries Review 43(1):13-20.

Islam, M. M. 2011. Living on the margin: the povertyvulnerability nexus in the small-scale fisheries of Bangladesh. Pages 71-95 in S. Jentoft and A. Eide, editors. Poverty mosaics: realities and prospects in small-scale fisheries. Springer, Dordrecht, The Netherlands. http://dx.doi.org/10.1007/978-94-007-1582-0_5

Jeppesen, G., and M. Richmond. 2016. Investment prioritization for climate-resilient livelihoods and ecosystems in the coastal zones of Tanzania. Overview. World Bank, Washington, D.C., USA. [online] URL: https://www.ndf.fi/sites/ndf.fi/files/attach/ overview publication january 2016.pdf

Jiddawi, N. S., and M. C. Öhman. 2002. Marine fisheries in Tanzania. AMBIO 31(7):518-527. http://dx.doi.org/10.1579/004$\underline{4-7447-31.7 .518}$

Johnson, D. S. 2010. Institutional adaptation as a governability problem in fisheries: patron-client relations in the Junagadh fishery, India. Fish and Fisheries 11(3):264-277. http://dx.doi. org/10.1111/j.1467-2979.2010.00376.x

Kabeer, N. 2003. Gender mainstreaming in poverty eradication and the millennium development goals: a handbook for policy-makers and other stakeholders. Commonwealth Secretariat, International Development Research Centre, Ottawa, Ontario, Canada. http:// dx.doi.org/10.14217/9781848598133-en

Kakwani, N. C. 1977. Applications of Lorenz curves in economic analysis. Econometrica 45(3):719-728. http://dx.doi.org/10.2307/1911684

Kininmonth, S., B. Crona, Ö. Bodin, I. Vaccaro, L. J. Chapman, and C. A. Chapman. 2016. Microeconomic relationships between and among fishers and traders influence the ability to respond to social-ecological changes in a small-scale fishery. Ecology and Society 22(2):26. http://dx.doi.org/10.5751/ES-08833-220226

Kleiber, D. L. 2014. Gender and small-scale fisheries in the Central Philippines. Dissertation. University of British Columbia, Vancouver, British Columbia, Canada.

Kleiber, D., L. M. Harris, and A. C. J. Vincent. 2015. Gender and small-scale fisheries: a case for counting women and beyond. Fish and Fisheries 16(4):547-562. http://dx.doi.org/10.1111/faf.12075

Kurien, J. 2005. Responsible fish trade and food security. Food and Agriculture Organization, Rome, Italy.

La Cour Madsen, B. 2003. Islands of development: What do poor women in Zanzibar get out of tourism liberalisation?. ActionAid Tanzania, Dar es Salaam, Tanzania.

Lefebvre, H., and D. Nicholson-Smith. 1991. The production of space. Vol. 142. Blackwell, Oxford, UK.

Lentisco, A., and R. Lee. 2015. A review of women's access to fish in small-scale fisheries. Food and Agriculture Organization, Rome, Italy.

Matsue, N., T. Daw, and L. Garrett. 2014. Women fish traders on the Kenyan coast: livelihoods, bargaining power, and participation in management. Coastal Management 42 (6):531-554. http://dx.doi.org/10.1080/08920753.2014.964819

McClanahan, T. R., and C. Abunge. 2017. Fish trader's gender and niches in a declining coral reef fishery: implications for 
sustainability. Ecosystem Health and Sustainability 3(6):1353288. http://dx.doi.org/10.1080/20964129.2017.1353288

Miñarro, S., G. N. Forero, H. Reuter, and I. E. van Putten. 2016. The role of patron-client relations on the fishing behaviour of artisanal fishermen in the Spermonde Archipelago (Indonesia). Marine Policy 69:73-83. http://dx.doi.org/10.1016/j.marpol.2016.04.006

Nayak, P. K., L. E. Oliveira, and F. Berkes. 2014. Resource degradation, marginalization, and poverty in small-scale fisheries: threats to social-ecological resilience in India and Brazil. Ecology and Society 19(2):73. http://dx.doi.org/10.5751/ ES-06656-190273

Neiland, A. E., and C. Béné. 2013. Poverty and small-scale fisheries in West Africa. Springer, Dordrecht, The Netherlands. http://dx. doi.org/10.1007/978-94-017-2736-5

Nurdin, N., and A. Grydehøj. 2014. Informal governance through patron-client relationships and destructive fishing in Spermonde Archipelago, Indonesia. Journal of Marine and Island Cultures 3 (2):54-59. http://dx.doi.org/10.1016/j.imic.2014.11.003

Office of Chief Government Statistician. 2013. December. Zanzibar Statistical Abstract 2012. Revolutionary Government of Zanzibar, Zanzibar.

Pastor, J. 2016. Women of the coast: life histories of deep-sea women fishers. Gender in Aquaculture and Fisheries: Engendering Security in Fisheries and Aquaculture. Report on the 6th Global Symposium on Gender in Aquaculture and Fisheries (GAF6), 3-7 August, Bangkok, Thailand.

Pavo, R. R. 2016. Between women space in the fish Port Tambler Complex and the value-chain nodes of the fishing industry in General Santos City, Philippines: an ethnographic study. Gender in Aquaculture and Fisheries: Engendering Security in Fisheries and Aquaculture. Report on the 6th Global Symposium on Gender in Aquaculture and Fisheries (GAF6), 3-7 August, Bangkok, Thailand.

Platteau, J.-P. 1989. Penetration of capitalism and persistence of small-scale organizational forms in Third World fisheries. Development and Change 20(4):621-651. http://dx.doi.org/10.1111/ j.1467-7660.1989.tb00360.x

Platteau, J.-P., and A. Abraham. 1987. An inquiry into quasicredit contracts: the role of reciprocal credit and interlinked deals in small-scale fishing communities. Journal of Development Studies 23(4):461-490. http://dx.doi.org/10.1080/00220388708422044

Pomeroy, R. S. 1990. The economics of production and marketing in a small scale fishery: Matalom, Leyte, Philippines. Dissertation Abstracts International. A, Humanities and Social Sciences 50 (9):3001-3002.

Pomeroy, R. S. 1992. Fish marketing in the Philippines: is the "suki" symbiotic or parasitic? Naga 15(3):13-14.

Pomeroy, R. S., and A. C. Trinidad. 1995. Industrial organization and market analysis: fish marketing. Pages 217-238 in G. J. Scott, editor. Prices, products and people: analyzing agricultural markets in developing countries. Lynne Rienner Publishers, Boulder, Colorado, USA.
Porter, M., R. Mwaipopo, R. Faustine, and M. Mzuma. 2008. Globalization and women in coastal communities in Tanzania. Development 51(2):193-198. http://dx.doi.org/10.1057/dev.2008.4

Riisgaard, L., S. Bolwig, F. Matose, S. Ponte, A. Du Toit, and N. Halberg. 2008. A strategic framework and toolbox for action research with small producers in value chains. DIIS working paper. Danish Institute for International Studies, Copenhagen, Denmark.

Riisgaard, L., S. Bolwig, S. Ponte, A. Du Toit, N. Halberg, and F. Matose. 2010. Integrating poverty and environmental concerns into value-chain analysis: a strategic framework and practical guide. Development Policy Review 28(2):195-216. http://dx.doi. org/10.1111/j.1467-7679.2010.00481.x

Ripley, B. D. 2001. The R project in statistical computing. $M S O R$ Connections. The newsletter of the LTSN Maths, Stats \& OR Network 1(1):23-25.

Siason, I. M. 2000. Women in fisheries in the Philippines. Review of Women's Studies 10(1-2).

SunStar Iloilo. 2017. Iloilo officials, Koica launch US\$5.5-M Concepcion port rehab. SunStar Iloilo, 1 February. [online] URL: http://www.sunstar.com.ph/iloilo/local-news/2017/02/01/iloilo-officialskoica-launch-us55-m-concepcion-port-rehab-523307

Suntornratana, U. 2003. Gender issues in small scale inland fisheries in Asia: women as an important source of information. Food and Agriculture Organization, Rome, Italy.

The East African. 2012. Zanzibar to build new port. The East African, 9 June. [online] URL: http://www.theeastafrican.co.ke/ business/Zanzibar-to-build-new-port/2560-1423714-dbhepwz/index. $\underline{\mathrm{html}}$

Thomas, J. P., and T. Worrall. 2000. Gift-giving, quasi-credit and reciprocity. Discussion Paper Series, Department of Economics, Department of Economics, University of St. Andrews, Fife, UK.

Thyresson, M., B. Crona, M. Nyström, M. de la Torre-Castro, and N. Jiddawi. 2013. Tracing value chains to understand effects of trade on coral reef fish in Zanzibar, Tanzania. Marine Policy 38:246-256. http://dx.doi.org/10.1016/j.marpol.2012.05.041

Thyresson, M., M. Nyström, and B. Crona. 2011. Trading with resilience: parrotfish trade and the exploitation of key-ecosystem processes in coral reefs. Coastal Management 39(4):396-411. http://dx.doi.org/10.1080/08920753.2011.589226

Tindall, C., and K. Holvoet. 2008. From the lake to the plate: assessing gender vulnerabilities throughout the fisheries chain. Development 51(2):205-211. http://dx.doi.org/10.1057/dev.2008.6

Torres, E. B., I. M. Pabuayon, and N. D. Salayo. 1987. Market structure analysis of fish distribution channels supplying Metro Manila [Philippines]. Deptartment of Agricultural Economics, University of the Philippines Los Banos, Laguna, Philippines.

Wamukota, A. 2015. The importance of selected individual characteristics in determining market prices for fishers and traders in Kenyan small-scale fisheries. Society and Natural Resources 28:959-974. http://dx.doi.org/10.1080/08941920.2015.1014600

Wamukota, A., T. D. Brewer, and B. Crona. 2014. Market integration and its relation to income distribution and inequality 
among fishers and traders: the case of two small-scale Kenyan reef fisheries. Marine Policy 48:93-101. http://dx.doi.org/10.1016/ j.marpol.2014.03.013

Westerman, K., and S. Benbow. 2013. The role of women in community-based small-scale fisheries management: the case of the southern Madagascar octopus fishery. Western Indian Ocean Journal of Marine Science 12(2):119-132.

Williams, M. 2016. Engendering security in fisheries and aquaculture. Gender in Aquaculture and Fisheries: Engendering Security in Fisheries and Aquaculture. Report on the 6th Global Symposium on Gender in Aquaculture and Fisheries (GAF6), 3-7 August, Bangkok, Thailand.

Wosu, A. 2017. The social-ecological dynamics of fisherwomen's behaviour in northern Mozambique. University of Edinburgh, Edinburgh, UK. 


\section{Appendix 1}

Zanzibar fisher interview

Date

Location /Study

Unique interview Code No.

Site. ....

Country

Data Collector

Fishery Type: Small Mixed Reef Fish $\square$ Small Pelagics $\square$ Octopus $\square$

Notes on the respondent? (Interviewed before?) Sex: Male $\square$ Female $\square$ Age:

SECTION 1: Fishing and Trade Characteristics

1a) Name the top species you most commonly land

1b) What gear and boat (if you use one) do you use to catch each species?

1c) Boat propulsion method (if boat used) for each species

1d) What species do you most want to land?

If using a boat:

2a. Do you own the boat you use? Yes No

b. If NO explain who does

3a. Do you own the gear you use? Yes No

b. If $\mathrm{NO}$ explain who does

4a. Do you always use a boat? Yes No

b. If NO explain

5. How long have your been fishing in this area? Explain your history and connection to this site

6. Fishing Effort Table KUSI

a. Time Spent Fishing

1. Hours per day:

(From leaving the beach till returning to the beach)

2. Days per week:

3. Weeks per month:

4. Months per year Kusi/Kaskazi is:

b. Number of hours gear is in the water per day?

Write down the gear they mentioned above in Q1

c. IF using a boat how many PEOPLE usually on board?

(This is to know how many fishers per piece of active gear)

d. IF USING a boat how many pieces of gear usually used on board?

(This is to know how many fishers per piece of active gear)

e. IF NOT USING a boat how many pieces of gear do you use?

(This is to know how many fishers to the different passive gears) 
-IF THEY USE MORE THAN ONE GEAR TYPE: when do they use each gear? The same day? Different days? How many times a week in Kusi do they use each?

7f. How many months a year do you spend fishing?

8a. SINCE YOU STARTED FISHING Has the types of species that you land changed over time? (NOT QUANTITY)

b. If YES how have they changed?

Yes No

c. Approximately when did this change occur?

9. What did you do before you were a fisher?

SECTION 2: Rent distribution (to be completed for each segment of the VC)

1. In regards to the most commonly landed species you mentioned earlier, what quantities $O N$ AVERAGE do you land and how much do you sell the products for in KUSI and KASKAZI?

a. Species

Average size in Kusi:

Small $\square$ Medium $\square$ Large $\square$

Average size in Kaskazi:

Small $\square$ Medium $\square$ Large $\square$

b. Average Quantities PER TRIP KUSI:

Bucket: $\square$ Equivalent in $\mathrm{Kg}=$

Basin: $\square$ Equivalent in $\mathrm{Kg}=$

Bunch:-Equivalent in $\mathrm{Kg}=$

Individuals: $\square$ Equivalent in $\mathrm{Kg}=$

How much money do YOU get?

Per quantity mentioned $\square$ Per Bucket $\square$ Per Basin $\square$

c. Average Quantities PER TRIP KASKAZI:

Bucket: $\square$ Equivalent in $\mathrm{Kg}=$

Basin: $\square$ Equivalent in $\mathrm{Kg}=$

Bunch: $\square$ Equivalent in $\mathrm{Kg}=$

Individuals: $\square$ Equivalent in $\mathrm{Kg}=$

How much money do YOU get?

Per quantity mentioned $\square$ Per Bucket $\square$ Per Basin $\square$

**UNITS used above need to be recorded and Translated into Measurable Units (Kg)

2a. Do you sell ALL of your catch in Kusi? Yes No 
[Probe: Do you give it away? Do you take some for home consumption? Do you store it in your freezer? What do you do with this unsold fish?]

2b. If NO what do you do with it?

-IF home consumption How MUCH on average in Kusi?

Which Species usually?

they give it away TO WHO

-IF they put in freezer HOW MUCH on average in Kusi?

-Other uses?

3a. Do you sell ALL of your catch in Kaskazi? Yes No

[Probe: Do you give it away? Do you take some for home consumption? Do you store it in your freezer? What do you do with this unsold fish?]

3b. If NO what do you do with it?

-IF home consumption How MUCH on average in Kaskazi?

Which Species usually?

-IF they give it away TO WHO?

-IF they put in freezer HOW MUCH on average in Kaskazi?

-Other uses?

4a. What costs are involved for you to go fishing?

$4 \mathrm{~b}$. If you received a loan, credit or a gift for any of the above please explain under what conditions

SECTION 3: Barriers to entry and upgrading opportunities

1. What are the KEY THINGS that you needed to become a fisher and start fishing?

[Probe: Social or material i.e. understand how they got into fishing.

If they mention an item different from above input costs ask them the cost]

2. What do you do to the fish/seafood before you sell it?

If you do anything explain when you started doing this and why

3. Would you like to engage in any other activity or job related to fishing or fish trade/processing activities?

4. What skills, assets, etc. do you think you would need to be able to do this?

5. Is there anything preventing you from doing this? Please explain

SECTION 4: Market conduct

1a. To whom or where do you sell your catch?

1b. How do you decide in WHERE or TO WHO you sell? Please elaborate. If they say market demand/good prices/good profit ask them HOW THEY KNOW about it

2a. If you ever sold to a customer or trader or hotel MORE THAN ONCE do you have an understanding with them? Yes No

Th If YFS what dnes it Innk like? 
[Probe: We have an agreement or contract? They own the boat? I owe them money?]

Explain what the agreement is like

2c. Why or how did the relationship start?

2d. Can you stop selling to this person anytime? Yes No

2e. What would happen if you stopped selling to this person?

3. How do you decide where and what to fish? If they say because customers want ask them how do they find out this information [Probe: Do customers make specific requests for species?]

4a. Do you have any understandings or informal/unofficial agreements or deals with other FISHERS? Yes No

[Probe: Do fishers call each other with information? What information? Do they share fish?]

4b. If YES please elaborate

5a. Do YOU ever bring the fish and sell the fish yourself at market? (IF its an auction do they BRING the fish there themselves?) Yes No

5b. If yes explain how it works e.g. how do you get there, which market, do you go alone, how often do you do it?

6. Are you a member of any organization or group related to fisheries? Explain your involvement briefly

7. How are the prices that you sell for determined? NOT INCLUDING AUCTION

[Probe: Do you set prices with the traders? Do you agree on the day? Do you have a customer that wants a certain price?] USE PROBES

SECTION 5: Relations affecting fisher and trader behaviour

1a. How many traders do you usually sell to in Kusi?

1b. How many traders do you usually sell to in Kaskazi

2a. Do you have any understandings or unofficial deals with anyone related to fishing NOT a trader or fisher? e.g. someone carries your fish? Someone fixes your nets? Someone prepares your vessel and gear to go fishing? Yes No

2b. If YES explain

THE NEXT FEW QUESTIONS ARE ABOUT RECEIVING HELP

3a. 1. Do you RECEIVE any continuous or frequent ASSISTANCE/HELP from any FISHERS? [Probe: Do you they give you money? Do they give you fish? Do you call them for help at sea?] TRANSLATE PROBES Yes No

3a. 2. If YES

What do they help you with?

3a. 3. How do you pay back? 
3b.1. Do you RECEIVE any continuous or frequent ASSISTANCE/HELP from any TRADERS?

[Probe: Do you they give you money? Do they give you fish? Do they give you fuel? Do they give you bait?] Yes No

3b.2. If YES

What do they help you with?

3b. 3. How do you pay back?

3c. 1. Do you RECEIVE any continuous or frequent ASSISTANCE/HELP from anyone else related to fishing NOT FISHERS OR TRADERS [Probe: Do you borrow money from the fishing association? Do the people who carry your fish help you? Do the people who fix your nets help you\} Yes No

3c. 2. If YES

What do they help you with?

3c. 3. How do you pay back?

THE NEXT FEW QUESTIONS ARE ABOUT PROVIDING HELP

4a. 1. Do you PROVIDE any continuous or frequent ASSISTANCE/HELP to any traders?

[Probe: Do you lend them money? Do you give them products? Do you give cheaper prices?

TRANSLATE PROBES Yes No

4a. 2. If YES

What do you help them with?

4a. 3. How do they pay you back?

4b. 1. Do you PROVIDE any continuous or frequent assistance to any fishers?

[Probe: Do you lend you money for damaged nets etc.? Do you give food for going fishing? Do you give you bait? Or petrol?] Yes No

4b. 2. If YES

What do you help them with?

4b. 3. How do they pay you back?

4c.1. Do you PROVIDE any continuous or frequent assistance to people related to fishing? [Probe: Do you who help people who carry your products? Who clean/cut your products? Who transport your products to markets or customers?] Yes No

4c.2. If YES

What do you help them with?

4c.3. How do they pay you back?

4a. Who would you ask for help in you had a fishing-related difficulty or needed something fishing-related? Please elaborate

4b. Who would you ask for help in you had a non-fishing-related difficulty or needed something not related to fishing? e.g. in the home, with family, medical etc. Please elaborate 
SECTION 6: Household material style of life indicators

1. Housing/room characteristics

2. Dwelling type

3. Wall material

4. Roof material

5. Floor

6. Do you own or rent this house / room?

7. In your house do you have any of the following Tick the box/circle alternative

Radio

Freezer

TV

VCR/DVD

Clock

Refrigerator

Electric fan

Satellite dish/Digital TV

Laptop/Computer

Land

8. Do you power your house in any way? (Electricity) Yes No

If YES what is your main source of power?

9. What is your main source of lighting (if any)?

10. Do you own a vehicle of any kind?

11. How do you normally cook food in the house?

12. Do you own any animals/livestock? Yes No

Types.

SECTION 7: Demographics

1. Please state your occupations and rank how much each contributes to your $\mathrm{CASH}$ and NONCASH income

Non-cash income can include for example provisioning services like food, building materials, household items or services they could receive for working at a or b

[Probe related to their fishing activities: Do they make dema's for cash? Do they build boats for cash? Do they make nets cash?]

2. Please state the different occupations of your household (including yourself) and rank how much each contributes to the household CASH and NON-CASH income

Non-cash income can include for example provisioning services like food, building materials, household items or services they could receive for working at a or b

3. Nationality

4. How many years have you lived/worked at this site?

5. Number of people in the household?

6. What is your highest level of education? 
Never gone to school, Primary, Secondary, University, Training College, Madrassa,

Other? Specify. 
Date Location /Study

Unique interview Code No

Site....

Country

Data Collector

Fishery Type: Small Mixed Reef Fish $\square$ Small Pelagics $\square$ Octopus $\square$

Notes on the respondent? (Interviewed before?) Sex: Male $\square$ Female $\square$ Age:

SECTION 1: Fishing and Trade Characteristics

1a. Name the top species you trade

[Probe: What they actually trade]

1b. What species do you most want to trade

2a. Has the types of species that you trade changed over time? Yes No

2b. If YES how have they changed?

2c. Approximately when did this change occur?

3. How do you transport your product?

4. How long have your been trading in this area? Explain your history and connection to this site

5. Do you trade alone or with a business partner(s)? Explain

6. What did you do before you were a trader?

SECTION 2: Rent distribution

1a. In regards to the most commonly traded species you mentioned earlier, what quantities on AVERAGE do you trade and what prices do you BUY and SELL the products for in KUSI?

\section{Species}

Average size:

Small $\square$ Medium $\square$ Large $\square$

2. Average Quantities Traded in KUSI PER DAY

Bucket:ロEquivalent in $\mathrm{Kg}=$

Basin: $\square$ Equivalent in $\mathrm{Kg}=$

Bunch:ロEquivalent in $\mathrm{Kg}=$

Individuals: $\square$ Equivalent in $\mathrm{Kg}=$

3. Purchase and Selling Prices in KUSI PER DAY Purchase Price:

Per quantity mentioned $\square$ Per Bucket $\square$ Per Basin $\square$

Per Bunch $\square$ Per fish?

Selling Price:

Per quantity mentioned $\square$ Per Bucket $\square$ Per Basin $\square$

Per Bunch $\square$ Per fish?

${ }^{* *}$ UNITS used above need to be recorded and Translated into Measurable Units (Kg) 
1b. In regards to the most commonly traded species you mentioned earlier, what quantities on AVERAGE do you trade and what prices do you BUY and SELL the products for in KASKAZI? 1. Species

Average size:

Small $\square$ Medium $\square$ Large $\square$

2. Average Quantities Traded in KASKAZI PER DAY

Bucket: $\square$ Equivalent in $\mathrm{Kg}=$

Basin: Equivalent in $\mathrm{Kg}=$

Bunch: $\square$ Equivalent in $\mathrm{Kg}=$

Individuals: $\square$ Equivalent in $\mathrm{Kg}=$

3. Purchase and Selling Prices in KASKAZI PER DAY

Purchase Price:

Per quantity mentioned $\square$ Per Bucket $\square$ Per Basin $\square$

Per Bunch $\square$ Per fish?

Selling Price:

Per quantity mentioned $\square$ Per Bucket $\square$ Per Basin $\square$

Per Bunch $\square$ Per fish?

${ }^{*}$ UNITS used above need to be recorded and Translated into Measurable Units (Kg)

2a. How many days a week do you trade in Kusi?

2b. How many days a week do you trade in Kaskazi?

3a. Do you sell ALL of your products in Kusi?

[Probe: Do you give it away? Do you take some for home consumption? Do you store it in your freezer? What do you do with this unsold fish?] Yes No

3b. If NO what do you do with it?

-IF home consumption How MUCH on average in Kusi?

Which Species usually

IF they give it away TO WHO?

-IF they put in freezer HOW MUCH on average in Kusi?

-Other uses?

4a. Do you sell ALL of your products in Kaskazi?

[Probe: Do you give it away? Do you take some for home consumption? Do you store it in your freezer? What do you do with this unsold fish?] Yes No

4b. If NO what do you do with it?

-IF home consumption How MUCH on average in Kaskazi?

Which Species usually?

IF they give it away TO WHO?

-IF they put in freezer HOW MUCH on average in Kaskazi?

-Other uses?

5a. What costs are involved for you to be able to trade? 
5b. If you received a loan, credit or a gift for any of the above please explain under what conditions

SECTION 3: Barriers to entry and upgrading opportunities

1. What did YOU need to become a trader and start trading? Understand how they got into trade. If they mention an item different from above input costs ask them the cost and how long the item lasts. [Probes: Materials? Social Connections? Skills?]

2. What do you do to the fish/seafood before you sell it?

If you do anything explain when you started doing this and why

3. Would you like to engage in any other activity or job related to fishing or fish trade/processing activities?

4. What skills, assets, etc. do you think you would need to be able to do this?

5. Is there anything preventing you from doing this? Please explain

SECTION 4: Market conduct

1. From Whom/Where do you a) buy your product and b) To whom or where do you sell your product?

1c. How do you decide in WHERE or FROM WHOM you buy? Please elaborate. If they say market demand/good prices/good profit ask them HOW THEY KNOW about it

1d. How do you decide in WHERE or TO WHO you sell? Please elaborate. If they say market demand/good prices/good profit ask them HOW THEY KNOW about it

2a. If you ever sold to a customer or trader or hotel MORE THAN ONCE do you have an understanding with them? Yes No

2b.If YES what does it look like?

[Probe: We have an agreement or contract? They own the boat? I owe them money?]

Explain what the agreement is like

2c. Why or how did the relationship start?

2d. Can you stop selling to this person anytime? Yes No

2e. What would happen if you did?

3. How do you decide which fishes/seafood to buy? If they say because customers want ask them how do they find out this information [Probe: Do customers make specific requests for species?]

4. How do you know when to come and buy your products at the landings sites, markets or auctions?

5a.Do you have any understandings or informal/unofficial agreements or deals with other TRADERS? Yes No

[Probe: Do traders discuss prices with each other? Do you pool products to sell together? Do you Transport to market together?] 
5b. If YES please elaborate

6. Are you a member of any organization or group related to fisheries? Explain your involvement briefly

7a. How are the prices that you buy your product for determined? NOT INCLUDING AUCTION Explain [Probe: Do you set prices with the fisher? Do you agree on the day? Do you have a customer that wants a certain price?]

7b. How are the prices that you sell for determined? NOT INCLUDING AUCTION Explain [Probe: Do you set prices with the fisher? Do you agree on the day? Do you have a customer that wants a certain price?]

SECTION 5: Relations affecting fisher and trader behaviour

1a. How many fishers do you usually buy from in Kusi?

1b. How many fishers do you usually buy from in Kaskazi?

2a. Do you have any understandings or unofficial deals with anyone related to fishing NOT a trader or fisher? [Probe: e.g. someone carries your fish? Someone sells it for you? Someone descales/cleans/cuts it for you?] Yes No

2b. If YES explain

3a. Do you have any fishers linked or tied to you? [Probe: are certain fishers obliged to sell to them for a certain reason? a favour? to repay a loan? We are trying to understanding whom they buy from]

Yes No

3b. If YES what does this arrangement look like?

3c. How many fishers are linked or tied to you?

THE NEXT FEW QUESTIONS ARE ABOUT RECEIVING HELP

4a. 1. Do you RECEIVE any continuous or frequent ASSISTANCE/HELP from any FISHERS?

[Probe: Do they give you money? Do you pay them later for products? Do they give you cheap

prices for some reason? Do they give you fish? Do they let you know what they have at sea?] Yes No

4a.2. If YES what do they help you with?

4a.3. How do you pay back?

4b.1. Do you RECEIVE any continuous or frequent ASSISTANCE/HELP from any TRADERS?

[Probe: Do they give you money? Do you pay them later for products? Do they give you fish?]

Yes No

4b.2. If YES what do they help you with?

4b.3. How do you pay back?

4c.1. Do you RECEIVE any continuous or frequent ASSISTANCE/HELP from anyone else related to fishing NOT FISHERS OR TRADERS? [Probe: Do you borrow money from the fishing association? Do the people who carry your fish or cut/clean it help you?] Yes No

4c.2. If YES what do they help you with?

4c.3. How do you pay back? 
4d. 1. Do you PROVIDE any continuous or frequent ASSISTANCE/HELP to any traders?

[Probe: Do you lend them money? Do you give them products? Do you give cheaper prices? Yes No

4d. 2. If YES

What do you help them with?

4d. 3. How do they pay you back?

4e. 1. Do you PROVIDE any continuous or frequent assistance to any fishers?

[Probe: Do you lend you money for damaged nets etc.? Do you give food for going fishing? Do you give you bait? Or petrol?] Yes No

4e. 2. If YES

What do you help them with?

4e. 3. How do they pay you back?

4f.1. Do you PROVIDE any continuous or frequent assistance to people related to fishing? [Probe: Do you who help people who carry your products? Who clean/cut your products? Who transport your products to markets or customers?] Yes No

\section{4f.2. If YES}

What do you help them with?

4f.3. How do they pay you back?

5a. Who would you ask for help in you had a fishing-related difficulty or needed something fishing-related? Please elaborate

$5 b$. Who would you ask for help in you had a non-fishing-related difficulty or needed something not related to fishing? e.g. in the home, with family, medical etc. Please elaborate

SECTION 6: Household/individual wealth

Tick the box/circle for each alternative

1. Housing/room characteristics

2. Dwelling type

3. Wall material

4. Roof material

5. Floor

6. Do you own or rent this house / room?

7. In your house do you have any of the following........

Radio

Freezer

TV

VCR/DVD

Clock

Refrigerator

Electric fan

Satellite dish/Digital TV

Laptop/Computer

Land

8. Do you power your house in any way? (Electricity) Yes No

If YES what is your main source of power?

9. What is your main source of lighting (if any)?

10. Do vou own a vehicle of anv kind? 
11. How do you normally cook food in the house?

12. Do you own any animals/livestock? Yes No Types

SECTION 7: Demographics

1. Please state your occupations and rank how much each contributes to YOUR CASH and NON$\mathrm{CASH}$ income

Non-cash income can include for example provisioning services like food, building materials, household items or services they could receive for working at $a$ or $b$

[Probe: related to their fishing activities: Do they make dema's for cash? Do they build boats for cash? Do they make nets cash?]

2. Please state the different occupations of your household INCLUDING YOURSELF AND YOUR OCCUPATIONS and rank how much each contributes to the household CASH and NON-CASH income

Non-cash income can include for example provisioning services like food, building materials, household items or services they could receive for working at a or b

3. Nationality

4. How many years have you lived/worked at this site?

5. Number of people in the household?

6 . What is your highest level of education?

Never gone to school, Primary, Secondary, University, Training College, Madrassa,

Other? Specify. 


\section{Philippines fisher interview}

INTERVIEW IDENTIFICATION

Interview ID

Municipality

Barangay

Name of Survey Participant (optional)

Name of Data Collector

Date of Interview

Interviewed before? Yes $\square$ No $\square$ Fishery Type: Small Mixed Reef Fish $\square$ Small Pelagics $\square$ Octopus ㅁ

Boat owner $\square$ Women Fryer $\square$ Hotel/Restaurant Trader $\square$ Exporter $\square$ Boat owner: Yes / No; Captain: Yes / No Group size: 1 / 2-4 / 5+ / Female Main Boat: Main Gear

\section{SECTION 1: DEMOGRAPHIC CHARACTERISTICS}

1

2

3

$4 a$

$4 \mathrm{~b}$ Responses)

1 -

2-

3-

5
Sex: 1 - Male 2- Female

Age:

Education : 1- primary__ 2- secondary 3- tertiary

How many years have you lived in this community? : Native 4- other or years

If not a native of this barangay, why did you move to this barangay? (Multiple

Got married from someone in this barangay

Found work in this barangay.

Others, specify

How many people live in your household? :

\section{SECTION 2: FISHING EXPERIENCE AND CHARACTERISTICS}

1

2

3 doing?

At what age did you start to fish?

Were your parents into fishing also at the time you started fishing? 1-yes 0 -no

What did you do before you were a fisher/When you weren't fishing what were you

4

What are the main spp. you catch and the gear and vessels used for each? Please provide details below. Additionally what species do you most want to catch?
a) Top species most commonly landed
b) Gear used for each spp.?
c) Vessel (if you use one) used for each spp.?
d) What species do you most want to land?

Can you please tell me more details about these gears?
a) Gear
b) Details [net type, mesh size, number of traps etc.
c) Who owns the gear? [e.g. 1-Respondent || 2-Respondent and someone else (record who) 3 - someone else (record who)]
d) How often do you use this gear? [1-Rarely || 2-Some trips || 3-Half of trips || 4-Most trips || 5-All trips]
e) Which times do you use each of these gears? [e.g. during a certain season; when I can borrow it; when I want to catch a special fish type; when it is rough weather] [IF no detailed response, ask: Why do you use gear A on some days and gear B on others? How do you decide whether to use gear $A$ or $B 1$ 
$6 \quad$ Do you use a fishing boat? 1- Yes 0 - No

If yes, please provide details below
a)Type (or 'None')
b) How is it powered? [1-Paddle || 2-Sail || 3-Inboard engine || 4-Outboard engine || 5-Other- describe]
c) Who owns the boat? [e.g. 1-Respondent || 2-Respondent and someone else (record who) 3 - someone else (record who]
d) How often do you use this boat? [1-Rarely || 2-Some trips || 3-Half of trips || 4-Most trips || 5-All trips]
e) Typically how many people fish together on this this boat?
f) What is your role on this boat? [e.g. Captain, crew]

\section{7a Where do you usually fish? (See Map)}

$7 \mathrm{~b} \quad$ How long have your been fishing in this area?

7c Where are your main landing sites/ places where you sell your catch? (multiple response allowed) e.g. Concepcion market, at sea, estancia etc.

7d Why do you choose to land/sell in these places?

7e 1) What months of the year is HABAGAT? Please circle

8

2) What months of the year is AMIHAN? Please circle

\section{SEASON 1 HABAGAT (South West Monsoon) May-Sept}

a) Time Spent Fishing (From leaving the beach till return)

1. Hours per day:

2. Days per week:

3. Weeks per month:

4. Months per Season 1

b) Number of hours gear is in the water per trip?

c) IF USING a boat how many pieces of gear usually used on board?

d) IF NOT USING a boat how many pieces of gear do you use?

SEASON 2 AMIHAN- (North East Monsoon) Oct-Jan

a) Time Spent Fishing (From leaving the beach till return)

1. Hours per day:

2. Days per week:

3. Weeks per month:

4. Months per Season 2

b) Number of hours gear is in the water per trip?

c) IF USING a boat how many pieces of gear usually used on board?

d) IF NOT USING a boat how many pieces of gear do you use?

How many Months a year do you fish?

11

a) Do you transport your fish to sell it? Yes / No?

b) How do you transport your product?

On-foo

Bicycle

Local Bus

Van Motorbike

Other? 


\section{SECTION 3: RENT DISTRIBUTION}

1 Referring to the most commonly caught species you mentioned earlier, what quantities ON AVERAGE do you land and how much do you sell the products in SEASON 1? a. Name of Species

Total Volume Caught

b. In local units

c. Equivalent in $\mathrm{kg}$

d. Qty consumed

e. Qty given away

f. Qty Stored/ Preserved

Sold

g. Quantity

h. Price $/ \mathrm{kg}$

2 Referring to the most commonly caught species you mentioned earlier, what quantities ON AVERAGE do you land and how much do you sell the products in SEASON 2? a. Name of Species

Total Volume Caught

b. In local units

c. Equivalent in $\mathrm{kg}$

d. Qty consumed

e. Qty given away

f. Qty Stored/ Preserved

Sold

g. Quantity

h. Price $/ \mathrm{kg}$

3

Input/Initial Costs

a) Can you tell me what fishing, storage, transport or marketing equipment you own or use?

b) How many do you have/use?

c)Who owns these? [e.g. 1-Respondent || 2-Respondent shares ownership (describe) 3 someone else

(describe who)]

d), e) + f) For the items you own, please tell me how much they cost, when you bought them and how long they typically last for.

$4 \quad$ Running Costs

What running costs are involved in your fishing activities?

a. Item

b. Individual/ Whole boat

1 -Individual

2- Whole boat

c. How frequent do you spend for this?

1 -

2-

Per trip

Daily

monthly

4- yearly

d. If you pay, costs?

e. If others pay, who pays?

$f$. Type of funds used $(P)$

1-saving, 2- loan 3-revolving fund 4- others, specify

g. What is the source of funds? 1-own 2 -trader 3 -others, specify 
What are the KEY THINGS that you needed to become a fisher and start fishing?

[Probe: Social or material i.e. understand how they got into fishing; if they mention an item different from above input costs ask them the cost]

2

Could you give an estimate of the total cost of acquiring what you have mentioned?
a) Requirements
b) Cost (if any)

3

What do you do to the fish/seafood before you sell it?

a. Do you do this to the fish before you sell them? 1-, 0-no

b. In what year did you start?

4

Would you like to engage in any other activity or job related to fishing or fish trade/processing activities? Multiple Responses Allowed [Probe: For example how would you like to see yourself working with fish in 10 years time?] 1-yes, 0- no

a. Please identify these activities in the cells below.

b. What skills, assets, etc. do you think you would need to be able to do this?

[If they say money ask how much]

c. Is there anything preventing you from doing this? Please explain

\section{SECTION 5: MARKET CONDUCT}

a. To whom or where do you sell your catch?

b. How many of these kinds of buyers do you sell to in Season 1? In Season 2?

c. Do they regularly buy fish from you?

d. Are there particular types of fish that you sell to this buyer? Which ones?

e. Where do you sell to them?

f. Do you know who they sell fish to?

g. Which buyer is most important for you in Season 1/ Season 2 [Circulate most important buyer].

$2 \quad$ Question

a. Of the people you sell to regularly (details needed),

b. What arrangement do you have with them? Do you help one another [e.g. set price / credit /

quantity / frequency / other / use their equipment]

c. How did you start that relationship?

d. What species do they want?

e. Could you stop selling to them? f. Why / why not

$3 \quad$ How do you decide WHERE or TO WHO you sell? Please elaborate. If they say market demand/good prices/good profit ask them HOW THEY KNOW about it

$4 \quad$ How do you decide where to fish?

$5 \quad$ How do you decide what to fish? If they say because customers want ask them how do they find out this information [Probe: Do customers make specific requests for species?]

6

Are you a member of any organization or group related to fisheries? 1-yes, $\quad$ 0-No

a. IF YES Explain your involvement briefly

$7 \quad$ How are the prices for your fish catch sold determined?

(e.g. Open-bidding; Secret-bidding; negotiations; Seasons; fishers decide as crew etc.)

Change back?

Do fishers LIKE YOU discuss what price to sell fish among themselves: 1-yes, 0-No 
Are prices influenced by the fish buyers? 1-yes, 0 -No

$11 \quad$ What can make the price of your fish be higher or lower?

$12 \quad$ What is the method of selling of your fish catch?

1 - sold on First come first serve basis

2 - Delivered to the commission house

3 - Others

\section{SECTION 6 : RELATIONS AFFECTING FISHER AND TRADER BEHAVIOR}

1 Do you have any understandings or informal agreements with other fishers? [Probe: Do fishers call each other with information? What information? Do they share fish?] 1 -Yes, O-No

a. If yes, please elaborate on this

$2 \quad$ Do you have any understandings or unofficial deals with anyone related to fishing NOT a trader or fisher? e.g. commission man? someone carries your fish? Someone fixes your nets? Someone prepares your vessel and gear to go fishing?

1-Yes, 0-No

a. If yes, please elaborate on this. Don't forget to mention who.

RECEIVING HELP

3 a. Do you RECEIVE any continuous or frequent ASSISTANCE/HELP from any

fishers? 1-Yes, 0-No

b. If YES

What do they help you with?

c. How do you pay back?

4

traders?

a. Do you RECEIVE any continuous or frequent ASSISTANCE/HELP from any

1-Yes, 0-No

b. If YES

What do they help you with?

5 a. Do you RECEIVE any continuous or frequent ASSISTANCE/HELP from anyone else related to fishing NOT a fisher or trader?

1 -Yes, 0-No

b. If YES .

What do they help you with?

Don't forget to mention who.

c. How do you pay back?

$6 \quad$ Who would you ask for help in you had a fishing-related difficulty or needed something that is related to your fishing activity?

$1-$

2- $\quad$ Predetermined buyer

3- $\quad$ Friend

4- $\quad$ Fellow fisher

5- $\quad$ Crew member

6- $\quad$ Fishing Association etc.

7- Myself

b. Location

1 - in the barangay

2 - next barangay

3 - next municipality 
4 - others

7

Who would you ask for help in you had a non-fishing-related difficulty or needed something not related to fishing? e.g. in the home, with family, medical etc.

$1-$

2- $\quad$ Predetermined buyer

a. Type of Relationship

3- $\quad$ Friend

4- $\quad$ Fellow fisher

5- Crew member

6- $\quad$ Fishing Association etc.

7- Myself

b. Location

1 - in the barangay

2 - next barangay

3 - next municipality

4 - others

1-Yes, 0-No

a. Do you PROVIDE any continuous or frequent ASSISTANCE/HELP to any fishers?

b. If YES

What do you help them with?

c. How do they pay you back?

1-Yes, O-No

a. Do you PROVIDE any continuous or frequent ASSISTANCE/HELP to any traders?

b. If YES

What do you help them with?

10 a. Do you PROVIDE any continuous or frequent ASSISTANCE/HELP to anyone else related to fishing NOT a fisher or trader?

1-Yes, O-No

b. If YES

What do you help them with?

Don't forget to mention who.

c. How do they pay you back?

SECTION 7: MATERIAL STYLE OF LIFE

1

What is the ownership status of the house/room where you currently reside?

$2 \quad$ Dwelling type

$3 \quad$ Wall material

$4 \quad$ Roof material

$5 \quad$ Floor

6 In your house do you have any of the following........ Tick the box/circle alternative

Radio

Freezer

TV

VCR/DVD

Clock

Refrigerator 
Electric fan

Satellite dish/Digital TV

Laptop/Computer

Land

Do you power your house in any way? (Electricity) 1-Yes, 0-No

8

If YES what is your main source of power?

9

What is your main source of lighting (if any)?

10

Do you own a vehicle of any kind?

11

How do you normally cook food in the house?

12

Do you own any animals/livestock? 1-Yes, 0-No

a. If yes what types:

SECTION 8: INCOMES

$1 \quad$ Please state YOUR occupations and rank how much each contributes to your CASH and $\mathrm{NON}-\mathrm{CASH}$ income

Non-cash income can include for example provisioning services like food, building materials, household items or services they could receive for working at a or b

$2 \quad$ Please state the different occupations of YOUR HOUSEHOLD (including yourself) and rank how much each contributes to the household $\mathrm{CASH}$ and NON-CASH income Non-cash income can include for example provisioning services like food, building materials, household items or services they could receive for working at a or b 


\section{Philippines trader interview}

INTERVIEW IDENTIFICATION

Interview ID

Municipality

Barangay

Name of Survey Participant (optional)

Name of Data Collector

Date of Interview

Interviewed before? Yes $\square$ No $\square$ Fishery Type: Small Mixed Reef Fish $\square$ Small Pelagics $\square$ Octopus $\square$

Boat owner $\square$ Women Fryer $\square$ Hotel/Restaurant Trader $\square$ Exporter $\square$ Also fishes: Yes / No

\section{SECTION 1: DEMOGRAPHIC CHARACTERISTICS}

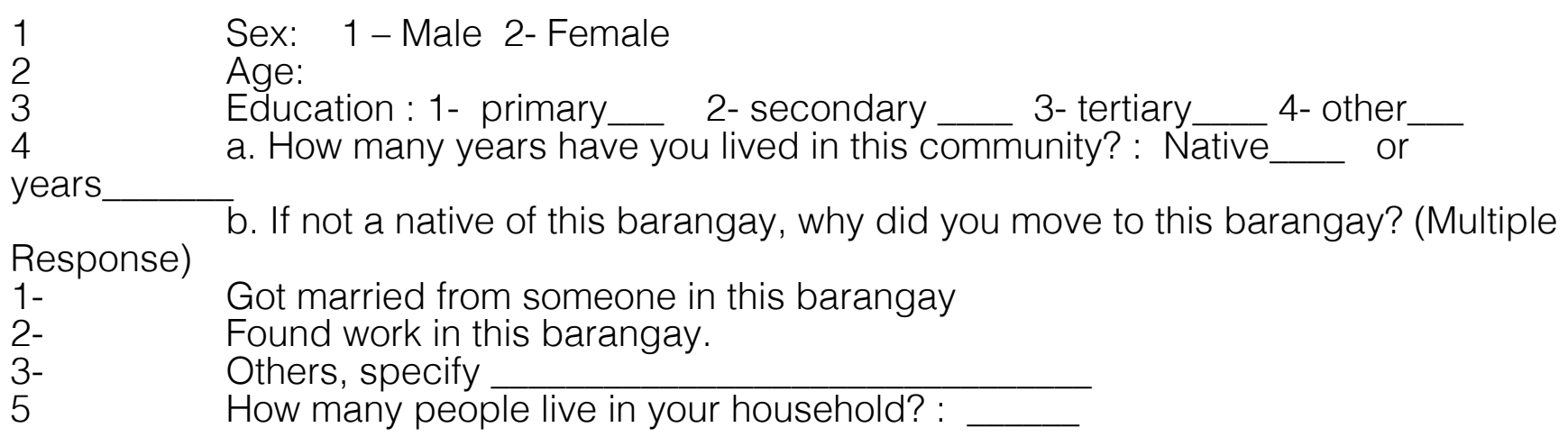

\section{SECTION 2: BUSINESS OPERATION/ TRADING CHARACTERISTICS}

$1 \quad$ How many years have you been trading fish in this area?

$2 \quad$ Do you trade alone or with a business partner(s)? 1- partnership 2- single 3-other, specify

What did you do before you were a fish trader?

4 want to trade?

What are the main species that you currently trade and what species do you most

a) Name the top spp. you trade [Probe: What they actually trade]

b) What species do you most want to trade?

5

a) Do you transport your fish to sell it? Yes / No?

b) How do you transport your product? (tick all that apply)

On-foot Bicycle Local Bus Van Motorbike Air Other?

6

a. How many employees do you have:

b. Type Number

paid (full-time) paid (part-time)

paid (family, full)

paid (family, part-time)

Not paid (family) 
Others, specify

1) What months of the year is HABIGAT? Please circle

2) What months of the year is AMIHAN? Please circle

\section{SECTION 3: RENT DISTRIBUTION}

$1 \quad$ Referring to the most commonly trade species you mentioned earlier, what quantities ON AVERAGE do you trade and how much do you sell the products for in SEASON 1?
a. Name of Species
Total Volume bought
b. In local units
c. Equivalent in $\mathrm{kg}$
d. Purchase price/KG
e. Qty consumed
f. Qty given away
g. Qty Stored/ Preserved
Sold
h. Quantity
i. Price $/ \mathrm{kg}$

$2 \quad$ Referring to the most commonly trade species you mentioned earlier, what quantities ON AVERAGE do you trade and how much do you sell the products for in SEASON 2?
a. Name of Species
Total Volume bought
b. In local units
c. Equivalent in $\mathrm{kg}$
d. Purchase price/KG
e. Qty consumed
f. Qty given away
g. Qty Stored/ Preserved
Sold
h. Quantity
i. Price $/ \mathrm{kg}$

How many days a week do you trade in SEASON 1?

4

How many days a week do you trade in SEASON 2?

5

Input/Initial Costs

a) Can you tell me what fishing, storage, transport or marketing equipment you own or use?

b) How many do you have/use?

c)Who owns these? [e.g. 1-Respondent || 2-Respondent shares ownership (describe) 3 someone else

(describe who)]

d), e) + f) For the items you own, please tell me how much they cost, when you bought them and how long they typically last for.

6

Running Costs

What running costs are involved in your fishing activities?
a. Item
b. Individual/ Whole boat 
1 -Individual

2- Whole boat

c. How frequent do you spend for this?

1 -

2-

3- monthly

4- yearly

d. If you pay, costs?

e. If others pay, who pays?

f. Type of funds used (PHP)

1-saving, 2- loan 3-revolving fund 4- others, specify

$\mathrm{g}$. What is the source of funds?

1-own

2 - trader

3 - others, specify

\section{SECTION 4: BARRIERS TO ENTRY AND UPGRADING OPPORTUNITIES}

$1 \quad$ What are the KEY THINGS that you needed to become a trader and start trading? [Probe: Social or material i.e. understand how they got into trading; if they mention an item different from above input costs ask them the cost]

Could you give an estimate of the total cost of acquiring what you have mentioned?
a) Requirements
b) Cost (if any)

$3 \quad$ In what form do you purchase the product?

1- gutted 2-whole 3- other processed (scaled, headed)

4

What do you do to the fish/seafood before you sell it?

a. Do you do this to the fish before you sell them? 1-Yes, 0-No

b. In what year did you start?

c. WHY?

$5 \quad$ Would you like to engage in any other activity or job related to fishing or fish trade/processing activities? [Probe: For example how would you like to see yourself working with fish in 10 years time?] 1-Yes, 0-No

a. Please identify these activities in the cells below.

b. What skills, assets, etc. do you think you would need to be able to do this? [If they say money ask how much]

c. Is there anything preventing you from doing this? Please explain

SECTION 5: MARKET CONDUCT

BUYING

1

a. From whom do you buy your products?

b. How many of these kinds of sellers do you buy from to in Season 1? In Season 2?

c. Do they regularly sell fish to you?

d. Are there particular types of fish that you buy from this seller? Which ones?

e. Where do you buy from them?

f. Do you know where they buy from? [if relevant]

g. Which seller is most important for you in Season 1/ Season 2 [Circulate most important seller].

$2 \quad B U Y I N G$

a. Of the people you buy from regularly (details needed),

b. What arrangement do you have with them? Do you help one another [e.g. set price / credit / quantity / frequency / other / use their equipment] 
c. How did you start that relationship?

d. What species do you want?

e. Could you stop buying from them? f. Why / why not

3

SELLING

a. To whom or where do you sell your products?

b. How many of these kinds of buyers do you sell to in Season 1? In Season 2?

c. Are there particular types of fish that you sell to this buyer? Which ones?

d. Do they regularly buy fish from you?

e. Where do you sell to them?

f. Do you know who they sell fish to?

g. Which buyer is most important for you in Season 1/ Season 2 [Circulate most important buyer].

4 SELLING

a. Of the people you sell to regularly (details needed),

b. What arrangement do you have with them? Do you help one another [e.g. set price / credit / quantity / frequency / other / use their equipment]

c. How did you start that relationship?

d. What do they want?

e. Could you stop selling to them? f. Why / why not

$5 \quad$ How do you decide WHERE or FROM WHO you buy? Please elaborate. If they say market demand/good prices/good profit ask them HOW THEY KNOW about it

$6 \quad$ How do you decide WHERE or to WHO you sell? Please elaborate. If they say market demand/good prices/good profit ask them HOW THEY KNOW about it

$7 \quad$ How do you decide what seafood to buy? If they say because customers want ask them how do they find out this information [Probe: Do customers make specific requests for species?]

$8 \quad$ Are you a member of any organization or group related to fisheries? 1-Yes, 0-No

a. IF YES Explain your involvement briefly

$9 \quad$ What is the usual method of payment when you purchase fish?:

1- cash and carry 2-credit 3- consignment 4-other, specify

$10 \quad$ How are the prices that you buy your product for determined? Explain [Probe: Do you set prices with the fisher? Do you agree on the day? Do you have a customer that wants a certain price?]

$11 \quad$ How are the prices that you sell for determined? Explain

[Probe: Do you set prices with the fisher? Do you agree on the day? Do you have a customer that wants a certain price?]

$12 \quad$ What can make the price of your fish be higher or lower?

Higher Lower

How do you get information on market prices? On supply? 
Do you have any understandings or informal agreements with other traders? [Probe:

Do traders discuss prices with each other? Do you pool products to sell together? Do you

Transport to market together?]

$1-$ Yes, 0-No

a. If yes, please elaborate on this

$2 \quad$ Do you have any understandings or unofficial deals with anyone related to fishing

NOT a trader or fisher? [Probe: e.g. someone carries your fish? Someone sells it for you?

Someone descales/cleans/cuts it for you?]

1-Yes, 0-No

a. If yes, please elaborate on this

3

Do you provide any support services to fishers? 1-Yes, 0-No

a. If yes, what is this support? (ex. credit, boat, gear)

4 a. Do you RECEIVE any continuous or frequent ASSISTANCE/HELP from any fishers? 1-Yes, 0-No

\section{RECEIVING HELP}

\section{b. If YES}

What do they help you with?

c. How do you pay back?

traders? 1-Yes, O-No

a. Do you RECEIVE any continuous or frequent ASSISTANCE/HELP from any

What do they help you with?

c. How do you pay back?

6 a. Do you RECEIVE any continuous or frequent ASSISTANCE/HELP from anyone else related to fishing NOT a fisher or trader?

1-Yes, 0-No

b. If YES

What do they help you with?

c. How do you pay back?

$7 \quad$ Who would you ask for help in you had a fishing-related difficulty or needed something that is related to your fishing activity?

a. Type of Relationship

1- Relative

2- $\quad$ Predetermined buyer

3- $\quad$ Friend

4- Fellow fisher

5- Other,

b. Location

1 - in the barangay

2 - next barangay

3 - next municipality

4 - others

$8 \quad$ Who would you ask for help in you had a non-fishing-related difficulty or needed something not related to fishing? e.g. in the home, with family, medical etc.

$1-$

a. Type of Relationship

Relative

2- $\quad$ Predetermined buyer 


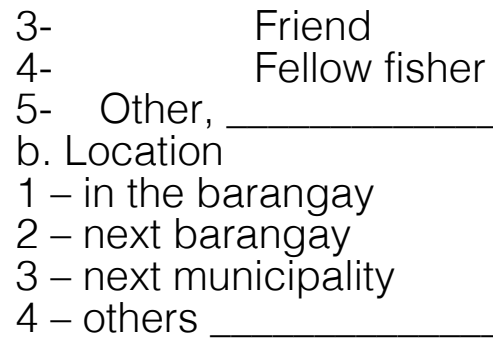

\section{PROVIDING HELP}

9 a. Do you PROVIDE any continuous or frequent ASSISTANCE/HELP to any fishers?

1-Yes, 0-No b. If YES

What do you help them with?

c. How do they pay you back?

10

1-Yes, 0-No

a. Do you PROVIDE any continuous or frequent ASSISTANCE/HELP to any traders?

What do you help them with?

c. How do they pay you back?

11 a. Do you PROVIDE any continuous or frequent ASSISTANCE/HELP to anyone else related to fishing NOT a fisher or trader?

1 -Yes, 0-No

b. If YES

What do you help them with?

c. How do they pay you back?

\section{SECTION 7: MATERIAL STYLE OF LIFE}

1

4 Roof material

$5 \quad$ Floor

Radio

Freezer

TV

VCR/DVD

Clock

Refrigerator

Electric fan

Satellite dish/Digital TV

Laptop/Computer

Land

Do you power your house in any way? (Electricity) 1-Yes, 0-No

If YES what is your main source of power? 
What is your main source of lighting (if any)?

11 How do you normally cook food in the house?

SECTION 8: INCOMES

1

Please state YOUR occupations and rank how much each contributes to your CASH and NON-CASH income Non-cash income can include for example provisioning services like food, building materials, household items or services they could receive for working at a or b

$2 \quad$ Please state the different occupations of YOUR HOUSEHOLD (including yourself) and rank how much each contributes to the household CASH and NON-CASH income Non-cash income can include for example provisioning services like food, building materials, household items or services they could receive for working at a or b 


\section{Appendix 2}

Sampling information for survey during data collection in the Philippines and Zanzibar.

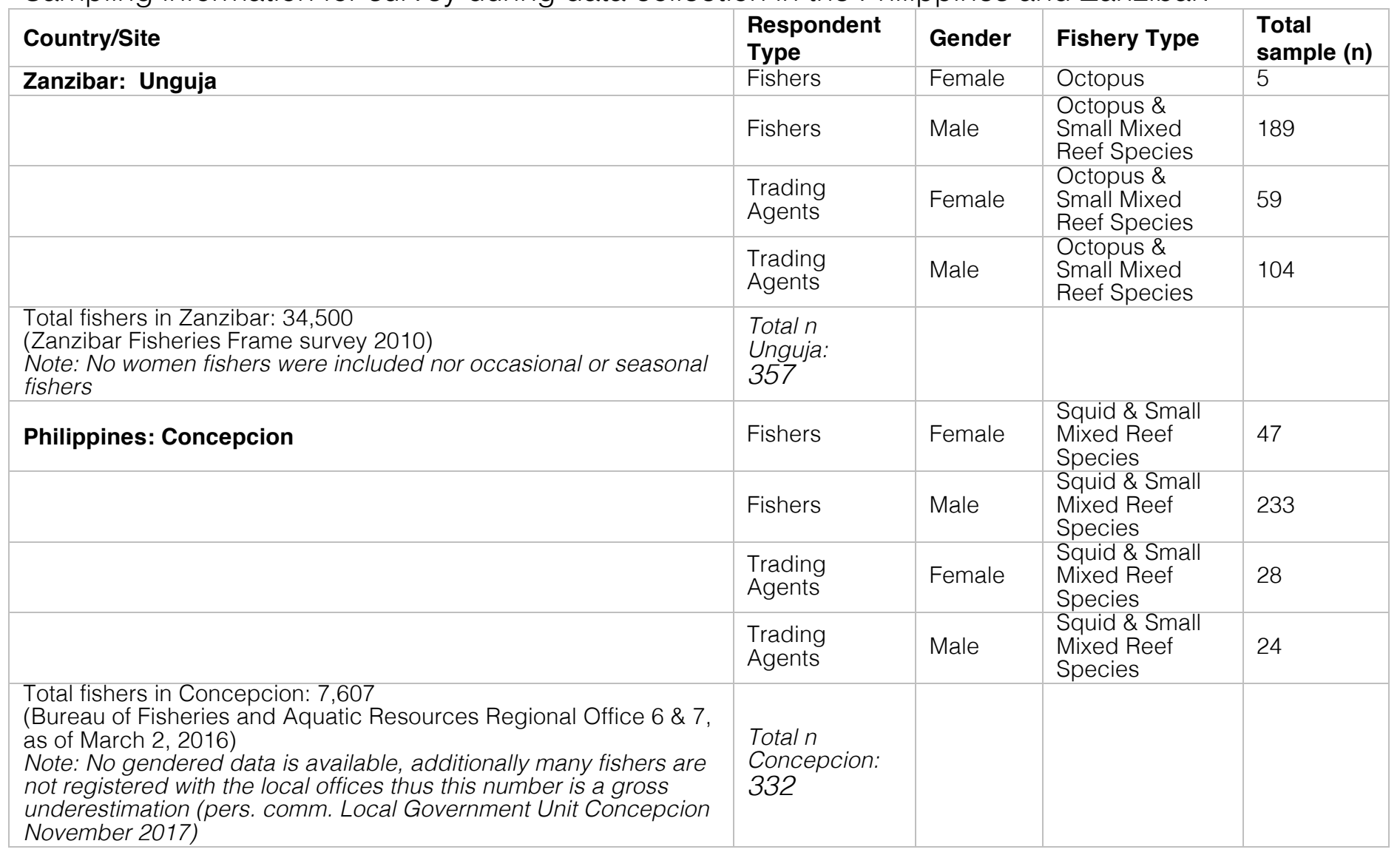




\section{Appendix 3}

\section{Unguja Island, Zanzibar}

The Zanzibar archipelago is a semi-autonomous region of Tanzania, a county formed by the union of Tanganyika and the People's Republic of Zanzibar in 1964 after the British terminated the Zanzibar protectorate. Zanzibar is comprised of two main islands, Unguja being the biggest at $1,666 \mathrm{Km}^{2}$, and Pemba, as well as many smaller islets. As of 2012 there was 896,721 people living in Unguja. This island archipelago is diverse in terms of its ethnic origins with a mix of Bantu, Swahili, Arab and Indian, whom predominately practice Islam. Zanzibar has a millennia old history of global trade that has strongly contributed to its unique cultural identity, including slaves, ceramics and spices, dating back to at least the 5th century and largely connected with the Gulf.

Traditionally Zanzibaris have never entirely depended on only one income, usually bringing together a range of income generating activities based on agriculture, animal husbandry, seaweed farming and fishing. In 2012 the largest contributor to Zanzibar's GDP was the service industry, largely linked to the huge growth in tourism, which in 2009 contributed a total 35\% to the country's GDP. However, the economy is still agriculturally based. 25\% of the population is employed by SSF while $98 \%$ of Zanzibaris rely on these seafood products for their animal protein intake (DoE Department of the Environment 2009). In 2015 Unguja 18.5\% of the population were classed as poor, or living under the National monetary poverty line (Belghith et al. 2017).

Coral reef associated species such as emperors, snappers, rabbitfish, parrotfish, groupers and goatfish are most commonly landed and are the most important for small-scale fisher folk due to their accessibility (Jiddawi and Öhman 2002). There are also fisheries for small-pelagics such as anchovies and scad (Jiddawi and Öhman 2002) Department of the Environment 2009) which are often exported across continental Africa as far as the Democratic Republic of the Congo (pers comm by respondents for another part of this project), as well as larger pelagics like tuna, swordfish and kingfish. Together these species make up over 70\% of Zanzibar's fishery landings (Jiddawi and Öhman 2002, DoE Department of the Environment 2009)

Today the SSF systems of Unguja are reported as degraded, fish biomass and biodiversity show decreases while there is admitted over-use of the coastal environment for resources i.e. coral reefs and mangroves (DoE Department of the Environment 2009, Crona et al. 2010). There are a range conservation issues currently impacting the system, for example the influx of migrant fishers, gender bias in trade, lack of law enforcement, destructive fishing gear and inadequate market systems (DoE, 2009).

SSF landings in Zanzibar are mainly consumed locally and high value seafood products like sea cucumbers, prawns, lobsters and seaweed currently reach the East Asian and European Markets, however, in very small amounts (approx. 200 Metric Tonnes per year) (DoE, 2009). Accordinaly Zanzibar does not have as strona a connection to alobal seafood trade as of vet 
(Jiddawi and Öhman, 2002), even so, trade liberalization since the nineties has contributed to the dissolution of many fishing cooperatives, from over twenty to just a handful, and cooperative shops, from over one hundred to only three (Maghimbi 2010). The tourist industry has profoundly impacted the fisheries and trade in the area introducing new market incentives, principles and financial systems.

\section{Concepcion, Iloilo}

The Municipality of Concepcion is part of the province of lloilo, which lies on the southern half of Panay Island in the Western Visayas Region (Region VI). Iloilo's socio-economic and political history has been greatly shaped by colonization by western powers. The vast majority of the population is Christian, specifically catholic. For hundreds of years lloilo experienced Spanish occupation (starting in 1566 and only ending in 1898) during which time the area began to economically prosper due to booming textile and sugar industries. After five decades of occupation by the U.S.A World War Two severely devastated the area and Iloilo experienced economic decline into the millennium. Today the capital of Iloilo is a hub for business, IT, real estate, shopping and medical centres, however north in the study area the economy is primarily based on the fishing industry.

The municipality of Concepcion, which includes all the fishing barangays in this study, boasts a population of 43,159 (as of august 2015, Philippine Population census). $36.8 \%$ of the population was classed as poor in 2012 according to a model based on income, expenditure and census data (PSA Releases the 2012 Municipal and City Level Poverty Estimate). Besides fishing, subsistence farming and cash crops like rice and corn support the local population however due to poor terrain in most of the islands these activities have traditionally been marginal. The Visayan sea is referenced as the world center of marine biodiversity (Ferrer 2009, 2016). In 2016 the most landed species at Concepcion port were Sardinella lemuru, Sardinella gibbosa, Photololigo duvaucelii, Rastrelliger brachysoma and Selaroides leptolepis; a mix of small pelgics and squid (National Stock Assessment Program 2017). However currently this hot spot of marine life is experiencing a dramatic depletion of resources (NEDA, 2011; Ferrer, 2009). The small-scale fishers who work in the area are experiencing, relative to the rest of lloilo, widespread poverty exacerbated by crashing fish stocks. Disturbances and drivers include management problems (lack of law enforcement, fishing registration) uncontrolled coastal land-use, illegal fishing, conflict between larger-sale and smaller-scale fishers, rapid technological increases and inefficient market systems (Ferrer, 2009).

Since the early 2000s roads, bridges and airports in Iloilo have all been upgraded to facilitate more international marine food trade (NEDA 2011). The Visayan Sea region is one of the top exporters of seafood in the Philippines thus strongly connected to global seafood markets 
(Hernando, 2005; NEDA, 2011). The SSF of the region market almost all landings, only negligible amounts are rejected by middlemen and used for household consumption (Hernando, 2005). In many parts of lloilo fishers sell $100 \%$ of crab and squid meant to the export market e.g. Taiwan, China, Japan (Hernando, 2005); typically the high value products like these as well as sea cucumbers, live groupers and lobsters are exported abroad (Perez et al. 2012). The current political agenda in the Philippines aims to capitalize the increasing global seafood demand by developing fisheries towards cheap consumer exports as a means to pay back major external debts (Ferolin and Dunaway, 2013). 


\section{Appendix 4}

\section{Fishers income calculations}

Season 1=> (kusi in Zanzibar and habagat in Philippines) Season 2=> (kaskazi in Zanzibar and amihan in Philippines).

$\mathrm{TSH}=$ Tanzanian Shillings PHP= Philippines Pesos

\section{A) GROSS INCOME calculations \\ Data extracted from Fisher Survey- Questions 1 Section 2 Survey Instrument Zanzibar \& Question 1 Section 3 Philippines, Question 6,7 Section 1 Zanzibar \& Questions 8,9 Section 1 Philippines.}

Landings were given in many different units thus needed standardizing to KG per person per day the fisher was fishing

Acronyms

$S=$ species

$\mathrm{D}=$ Day

$\mathrm{A}=$ Active

$\mathrm{P}=$ Person

$\mathrm{V}=$ Value

$\$=$ International USD

$\mathrm{Gl}=$ gross income

$\mathrm{PPP}=$ Purchasing Power Parity

1) Buckets, basins and individual species landed were converted to KG according the weight estimations given by fishers. If a respondent made no KG estimations then estimations from the same landing site for the same species/bucket/basin sizes were taken. This gave us- KG Landed Per Day Per Species Season 1= KG1; KG Landed Per Day Per Species Season 2=KG2

2) Next the "annual" average KG landed per day was calculated with the average KG landed per day in season 1 and average KG landed per day in season 2. This average was divided by the number of people (crew, captain) associated with the landing to give the Average KG Landed Per Day Per Species Per Person (KGDSP)

$((\mathrm{KG} 1+\mathrm{KG} 2) / 2)) / \# \mathrm{Crew}=\mathrm{KGDSP}$

3) Fishers were asked to state the estimated amount of money (in local units) they themselves got in accordance with the landings they stated for each day per season. This excludes the need to deal with the "sharing system" (typical on most small-scale fishing vessels with more than one owner/captain) i.e. where part of the days profit goes to the vessel, the majority to the owner, some to the captain and relatively less to crew-only members. This value for season 1 (V1) and season 2 (V2) was averaged to get an "Annual" Average Daily Value per Species per Person in TSH or PHP; used in place of (but not the same as) a sales prices for the calculations.

$(\mathrm{V} 1+\mathrm{V} 2) / 2=\mathrm{VDSP}$

4) The local units (Philippines pesos and Tanzanian shillings) for the average value received per day (step 3) were then converted to international US Dollars with the appropriate purchasing power parity PPP conversion factors (Factfish 2016). This step gave the Annual Average Daily Value Per Species Per Person in international Dollars.

$(\mathrm{VDSP} / \mathrm{PPP})=\mathrm{VDSP} \$$ 
5) The VDSP\$ was then divided by the "annual" average volume landed (KGDSP - step 2). As the values were associated with many different types of weight units and for two different seasons-> they were converted to per KG values with KGDSP to give an Annual Average Daily Value Per Species Per Person Per KG in international USD.

\section{VDSP\$/ KGDSP $=$ VKG \$}

6) Fishing effort is not evenly distributed across the year. This was accounted for to make sure gross income was accurate for the days the fishers were actually out fishing (and so as not to over-estimate the final incomes). This was done by getting the active days per year for individual fishers (Question 6,7 Section 1 - Zanzibar; Questions 8,9 Section 1 - Philippines). A season average was taken for the months, days and weeks to get the average numbers in the calculation. Active Months Per Year (M), Active Days Per Week (D), and the Average Weeks Per Month (W) were all multiplied to get Active Days Per Year for each fisher (DY).

$M * D * W=D Y$

** This calculation was not included in the first set of calculations pre-may 2017

7) The value calculated in step 5 was converted to a standardized value for the Average Value Per Year Per Species Per KG Per Person in international USD.

$D Y^{\star} V K G \$=V K G Y \$$

** This calculation was not included in the first set of calculations pre-may 2017

8) The yearly values from step 5 was then divided by the number of days a fisher was active throughout the year according to the effort data to get Average Value Per Active Day Per Species Per KG Per Person in international USD

VKGY\$/DY = VKGA\$

** This calculation was not included in the first set of calculations pre-may 2017

9) Finally the gross income was calculated by taking into account the quantities fishers were landing on average across the year on a daily basis, to get an Average Value Per Active Day Per Species Per Person in international USD

VKGA $\$$ *KGDSP $=$ VADSP $\$$

10) The VADSP\$ was summed for each individual fisher to account for the different species they were are landing. The Final unit was an Annual Average Active Daily Gross Income Per Person in international USD

$=>\operatorname{G} \mid \$$

OBS We assessed each species that fishers landed, however what they land on a daily basis varies according to many factors including season and weather and they can land multiple species on the same day. We chose to work at the species level to try and link the fishing activities and market to ecosystem dynamics. However separating the catch into species and then summing the final values will result in overestimation of fishers' earnings for some days. This can be seen in the positive skews of the boxplots in the paper. 
If, on the other hand, an average volume landed was taken across all the different species a fisher was landing this resulted in a much bigger under estimation of the yearly catch. When running costs were brought into the calculations this then leads to many negative net incomes. After working through the different types of income calculations and assumptions we decided that the most accurate estimation of daily gross incomes was to sum the set of species.

B) RUNNING COST Calculations

Data extracted from Fisher Survey- Question 4a Section 2 Zanzibar \& Question 4 Section 3 Philippines, Question 6,7 Section 1 Zanzibar \& Questions 8,9 Section 1 Philippines.

Fishers' costs were given in many different time units (days, weeks, biweekly, 6 moths, year etc.) thus the first thing was to standardize costs to the days that fishers were active. Running costs were taken as those costs that fishers incurred yearly or in any time span less than a year i.e. daily, weekly, monthly, and were separated from the bigger investment costs that fishers might make on a more-longer term basis.

1) The costs for the different time units the fishers used were converted into single unit costs as follows

Each cost (C) was identified individually as either a simple per unit cost i.e. per day, per week or per month; or if the costs were more or less than a simple unit e.g. per 3 weeks, twice a day.

For example $50 \mathrm{TSH}$ on salt 3 times per day, the unit was identified as day, the time unit as 3 . The cost per day (Time Unit TU) was thus multiplied by 3 (Per Unit PU). If not a simple per unit cost then the costs were converted to get a Cost Per Unit in TSH/PHP

$C^{*} T{ }^{*} P U=C P U$

2) Costs were then checked to see if they were paid by the fisher, by the captain, the crew or the boat owner, which was captured in the surveys. "CPU" were then divided by the appropriate number; if the fisher didn't incur the cost it was divided by 0.

$=$ CPUP

3) The days fishers were active and thus incurring costs were then brought into the calculations. The individual costs were converted into yearly costs.

Average \# Weeks Per Month= W

Active Months Per Year=M

Active Days Per Week= D

If the costs was per

Year $=$ CPUP*1

Month $=C P U P^{*} M{ }^{*} P U$

Week $=C P U^{*} M^{*} W * P U$

Day $=C P U^{*} M^{*} D^{*} W^{*} P U$

This step provided the Cost Per Unit Per Person Per Year in TSH or PHP= CPUPY

4) Similar to what was done for gross income, the yearly costs from step 3 were converted down to daily costs for days the fishers were actually active; the Active Days Per Year (DY) were taken from the gross income calculations to calculate a Cost Per Unit Per Person Per Active Day in TSH or PHP (CPUD) 
$(\mathrm{CPUPY}) / \mathrm{DY}=\mathrm{CPUD}$

5) Costs were converted to international dollar using the conversion factor PPP (see gross income costs) to get a Cost Per Unit Per Person Per Active Day now in international USD

$(\mathrm{CPUD}) / \mathrm{PPP}=\mathrm{CPU} \$$

6) We then summed all the costs for each fisher to have a final running cost total per individual, so a Cost Per Person Per Active Day in International USD.

$=>C \$$

C) NET INCOME calculations

The gross income values were used and the running costs taken away to give a Net Income

Per Person Per Active Day in international USD

$\mathrm{GI} \$-\mathrm{C} \$=\mathrm{N} \mid \$$

Trader income calculations

A) GROSS INCOME calculations

Data extracted from Trader Survey- Question 1a,b Section 2 Zanzibar \& Question

1 Section 3 Philippines, Question 2a,b Section 2 Zanzibar \& Question 2,3 Section 3 Philippines

Quantities trader were given in many different units thus needed standardizing to KG per person per day the trader was active

Acronyms

$\mathrm{S}=$ species

D= Day

$A=$ Active

$P=$ Person

$\mathrm{V}=$ Value

$\$=$ International USD

$\mathrm{Gl}=$ gross income

$\mathrm{PP}=$ Purchase Price

$\mathrm{SP}=$ Sales Price

$\mathrm{PPP}=$ Purchasing Power Parity

1) Average buckets, basins and individual species traded daily were converted to KG according the weight estimations given by traders. If a respondent made no KG estimations then

estimations from the same landing sites/markets for the same species/bucket/basin sizes were taken. This gave us KG Traded Per Day Per Species Season 1=KG1 and the KG Traded Per Day Per Species in Season 2=KG2

2) Next the "annual" average KG trader per day was calculated with the average KG traded per day in season 1 and average KG traded per day in season 2. This average was divided by partner numbers where relevant to get an Annual Average KG Traded Per Day Per Species Per Person

$((\mathrm{KG} 1+\mathrm{KG} 2) / 2)) / \#$ Partners $=\mathrm{KGDSP}$ 
3) Traders were asked to estimate the purchase prices per species across the two seasons (PP1 \& PP2), they responded in a variety of units i.e. per bucket, per KG so the purchase prices were converted to per KG and the seasonal variations were taken into account by getting an average. This step provided an Annual Average Purchase Price Per Species Per KG Per Person in TSH or PHP

$((\mathrm{PP} 1+\mathrm{PP} 2) / 2) / \mathrm{KGDSP}=\mathrm{APP}$

4) The same thing was then done with the sales prices (SP1 \& SP2 for each season) the traders reported for each season to get an Annual Average Sales Price Per Species Per KG Per Person in TSH or PHP

$((\mathrm{SP} 1+\mathrm{SP} 2) / 2) / \mathrm{KGDSP}=\mathrm{ASP}$

5) Now a Gross income value (Gross Income Per Day Per Species Per Person in TSH or $\mathrm{PHP}$ ) could be calculated by using the sales and purchase prices in combination with the KG traded.

$(A S P-A P P)^{*} K G D S P=G I D S P$

6) As with the fishers the local currencies (Philippines pesos and Tanzanian shillings) were then converted to international US Dollars with the appropriate purchasing power parity PPP conversion factors (Factfish 2016). Giving a Gross Income Per Day Per Species Per Person in international USD

$($ GIDSP /PPP $)=$ GIDSP \$

7) Trading effort according to time was then taken into account to make sure this gross income was accurate for the days the traders were actually working, so as not to over-estimate the final incomes. This was done by getting the active days per year (DY) for individual traders with the effort data they gave us- See survey Question 2a,b Section 2 Zanzibar \& Question 2,3 Section 3 Philippines. An assumption had to be made here for the months traders were active per year (M); this data we failed to collect in the survey thus an informed estimate had to be made according to fieldwork and data from the SPACES project.

Average \# Weeks Per Month = W

Active Months Per Year=M

Active Days Per Week= D

$M^{\star} D^{\star} W=D Y$

** This calculation was not included in the first set of calculations pre-may 2017

8) Gross income was converted to a yearly value as a means to get the data back down to active days, to get a Gross Income Per Year Per Species Per Person in international USD

\section{$M^{\star} D^{\star} W^{\star}$ GIDSP $\$=G I Y \$$}

** This calculation was not included in the first set of calculations pre-may 2017 
9) The yearly values from step 8 were then divided by the number of days traders were active throughout the year according to the effort data to give a final gross income still per speciesGross Income Per Active Day Per Species Per Person in international USD.

GIY\$/DY= GIDS\$

** This calculation was not included in the first set of calculations pre-may 2017

10) The Gross Income Per Active Day Per Species Per Person (International USD)GIDS\$ were summed for each individual trader to account for the different species they were trading.

The final unit being the Gross Income Per Active Day Per Person (International USD)

$=>\mathrm{G} \mid \$$

OBS As traders also deal with multiple species on the same day, varying across seasons and years, the same potential for overestimation is present here as with the fishers, see OBS in the fishers calculations above.

B) RUNNING COST Calculations

Data extracted from Trader Survey- Question 5a Section 2 Zanzibar \& Question 4 Section 3 Philippines, Question 2a,b Section 2 Zanzibar \& Question 5 Section 3 Philippines

Traders' costs were given in many different time units (days, weeks, biweekly, 6 moths, years etc.) thus the first thing was to standardize costs to the days that traders were active. Running costs were taken as those costs that traders incurred yearly or in any time span less than a year i.e. daily, weekly, monthly. Thus were separated from the bigger investment costs that traders might make on a more-longer term basis.

1) The costs for the different time units the traders used were converted into single unit costs as follows

Each cost (C) was identified individually as either a simple per unit cost i.e. per day, per week or per month; or if the costs were more or less than a simple unit e.g. per 3 weeks, twice a day.

For example $50 \mathrm{TSH}$ on salt 3 times per day, the unit was identified as day, the time unit as 3 . The cost per day (TU) was thus multiplied by 3 (PU). If not a simple per unit cost then the costs were converted to get a Cost Per Unit in TSH/PHP

$C * T U * P U=C P U$

2) Costs were then checked to see if they were paid by the trader or by a partner or business owner, which was captured in the interviews. CPU was then divided by the appropriate value; if the trader didn't pay it was divided by 0 .

$=$ CPUP

3) The days traders were active and thus incurring costs were then brought into the calculations.

The individual costs were converted into yearly costs.

Average \# Weeks Per Month $=W$

Active Months Per Year=M

Active Days Per Week=D

If the costs was per 
Year $=\mathrm{CPUP}^{\star} 1$

Month $=C P U P * M * P U$

Week $=C P U^{*} M^{*} W * P U$

Day $=C P U^{*} M^{*} D^{*} W^{*} P U$

This step provided the Cost Per Unit Per Person Per Year in TSH or PHP $=$ CPUPY

** This calculation was not included in the first set of calculations pre-may 2017

4) The yearly costs from step 3 were then taken down to daily costs for days the traders were actually active i.e. to get the Cost Per Unit Per Person Per Active Day in TSH/PHP; the Active Days Per Year (DY) were taken from the gross income calculations.

$(\mathrm{CPUPY}) / \mathrm{DY}=\mathrm{CPUD}$

** This calculation was not included in the first set of calculations pre-may 2017

5) Costs were converted to international dollar using the conversion factor PPP (see gross income costs) to get a Cost Per Unit Per Person Per Active Day international USD

$(\mathrm{CPUD}) / \mathrm{PPP}=\mathrm{CPU} \$$

6) We then summed all the costs for each trader to have a final running cost total per individual Per Active Day in international USD

$=>C \$$

C) NET INCOME calculations

The gross income values were used and the running costs taken away to give a Net Income Per Person Per Active Day in international USD

$\mathrm{GI} \$-\mathrm{C} \$=\underline{N} \mid \$$ 


\section{Appendix 5}

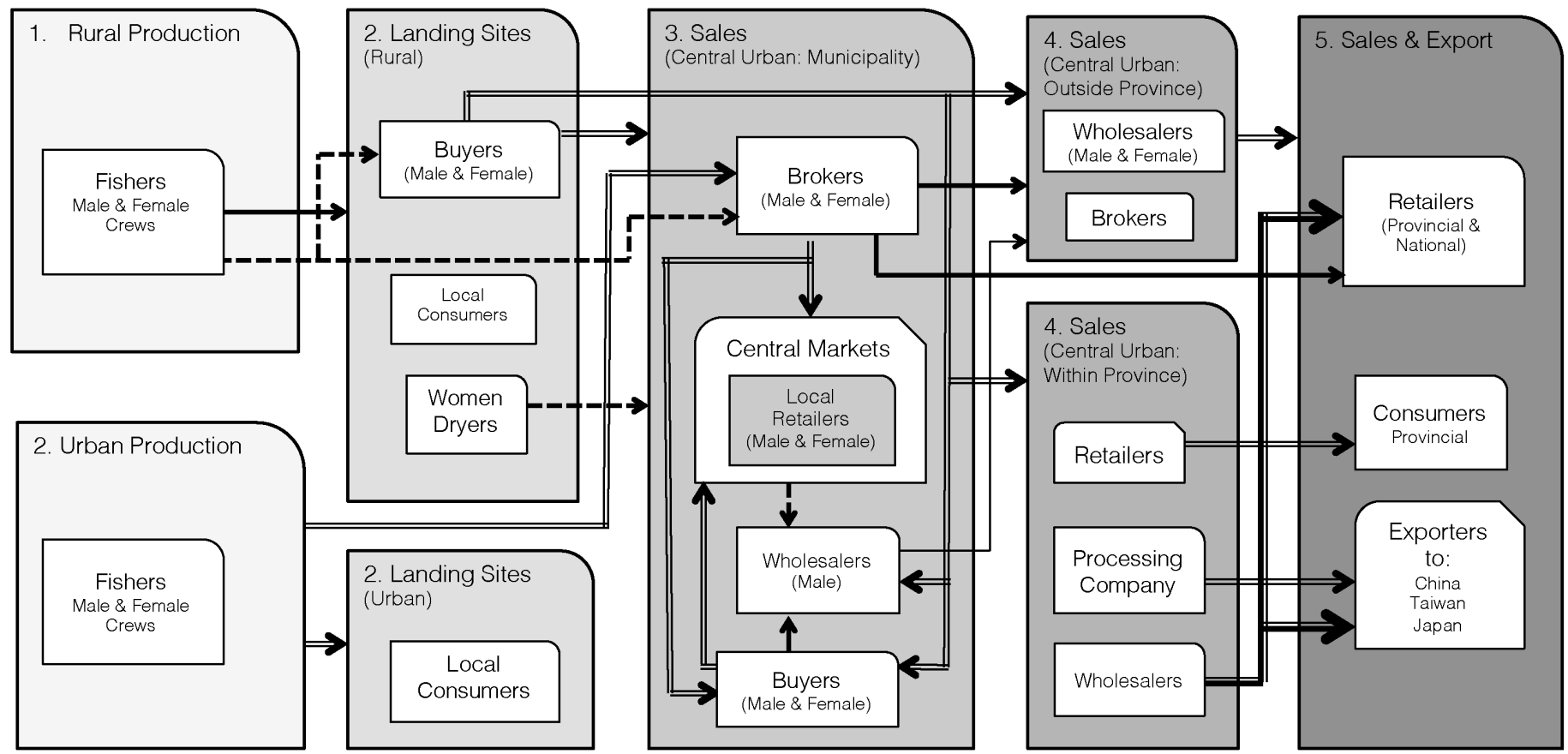

Figure A5.1: Market structure for Concepcion Municipality, Philippines. Dotted arrows represent the product being sold by women actors, the bold line represents men actors and the double line shows both women and men transactions. Different sized arrows are used only for clarity.

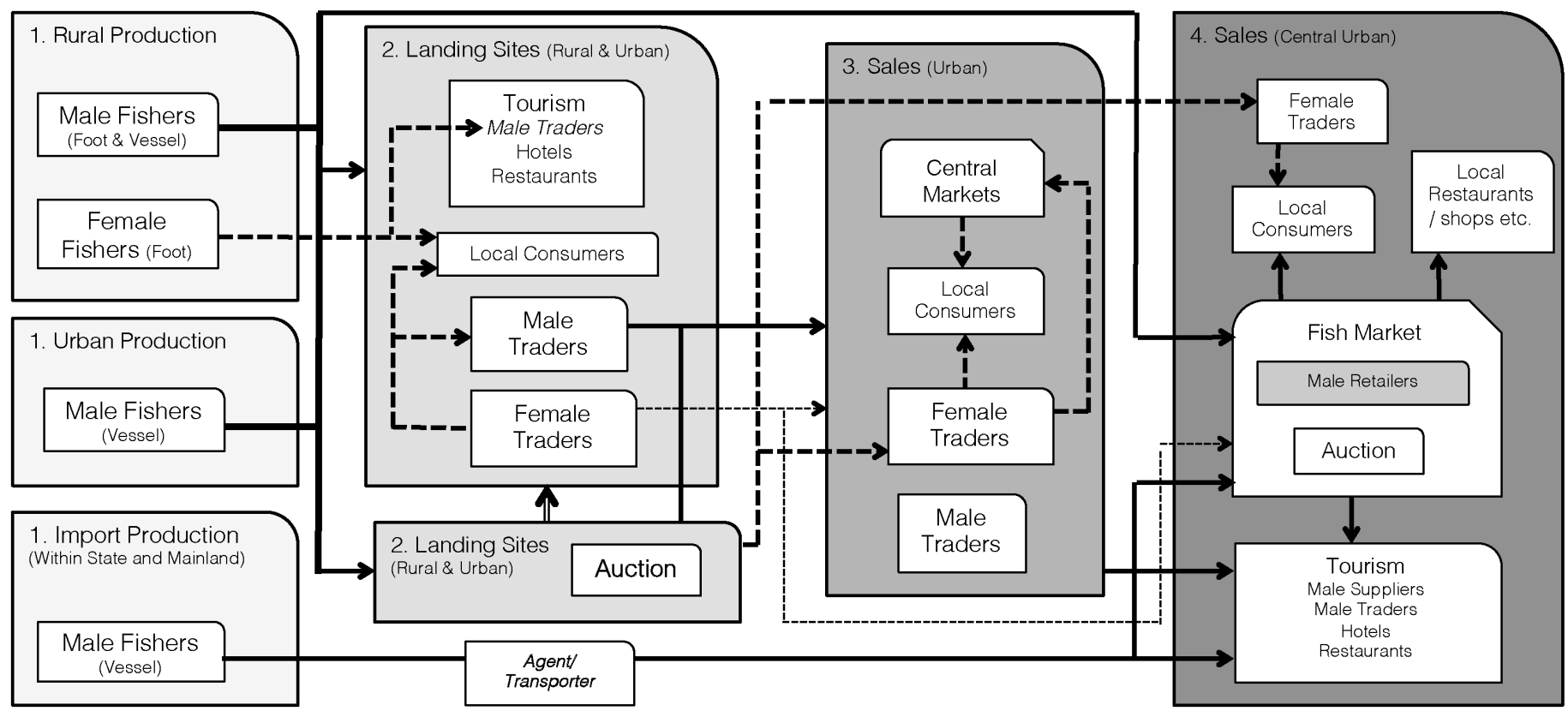

Figure A5.2: Market structure for Unguja Island (Zanzibar). Dotted arrows represent the product being sold by women actors, the bold line represents men actors and the double line shows both women and men's transactions. Different sized arrows are used only for clarity. 


\section{Appendix 6}

The exchange of assistance between fishers and traders in Unguja and Concepcion.

Percentages represent frequency of responses of actor types i.e. fishers or traders, receiving from or providing to the other nodes. The types of assistance are described in the adjoined cells as well as the mechanisms for paying back debt. $F=$ women, $M=$ men.

\begin{tabular}{|c|c|c|c|c|c|}
\hline $\begin{array}{l}\text { Zanzibar: } \\
\text { Assistance } \\
\text { Between } \\
\text { Fishers \& } \\
\text { Trading } \\
\text { Agents }\end{array}$ & & & $\begin{array}{l}\text { Philippines: } \\
\text { Assistance } \\
\text { Between } \\
\text { Fishers \& } \\
\text { Trading } \\
\text { Agents }\end{array}$ & & \\
\hline Actor Type & $\%$ Receiving & \% Providing & Actor Type & $\%$ Receiving & $\%$ Providing \\
\hline $\begin{array}{l}\text { Rural Fishers } \\
\text { (F) }\end{array}$ & $0(n=5)$ & $20(n=5)$ & $\begin{array}{l}\text { Rural Fishers } \\
(F \& M)\end{array}$ & $75.5(n=200)$ & $5.5(n=200)$ \\
\hline $\begin{array}{l}\text { Rural Fishers } \\
\text { (M) }\end{array}$ & $57.5(n=120)$ & $59(n=85)$ & $\begin{array}{l}\text { Urban Fishers } \\
(F \& M)\end{array}$ & $51(n=51)$ & $3.92(n=51)$ \\
\hline $\begin{array}{l}\text { Urban Fishers } \\
\text { (M) }\end{array}$ & $32(n=38)$ & $42(n=32)$ & - & - & - \\
\hline $\begin{array}{l}\text { Rural Trading } \\
\text { Agents }(F)\end{array}$ & $40(n=25)$ & $56(n=25)$ & $\begin{array}{l}\text { Rural Trading } \\
\text { Agents } \\
(F \& M)\end{array}$ & $25(n=20)$ & $100(n=21)$ \\
\hline $\begin{array}{l}\text { Rural Trading } \\
\text { Agents (M) }\end{array}$ & $67(n=42)$ & $71.5(42)$ & $\begin{array}{l}\text { Urban Trading } \\
\text { Agents } \\
(F \& M)\end{array}$ & $0(n=17)$ & $50(n=17)$ \\
\hline $\begin{array}{l}\text { Urban Trading } \\
\text { Agents }(F)\end{array}$ & $0(n=21)$ & $4.8(n=21)$ & - & - & - \\
\hline $\begin{array}{l}\text { Urban Trading } \\
\text { Agents }(M)\end{array}$ & $37(n=43)$ & $50(n=42)$ & - & - & - \\
\hline $\begin{array}{l}\text { Help Type } \\
\text { Description }\end{array}$ & $\begin{array}{l}\text { Pay back } \\
\text { mechanisms }\end{array}$ & & $\begin{array}{l}\text { Help Type } \\
\text { Description }\end{array}$ & $\begin{array}{l}\text { Pay back } \\
\text { mechanisms }\end{array}$ & \\
\hline $\begin{array}{l}\text { From Trading } \\
\text { Agents to Fishers: } \\
\text { Cash loans for fuel, } \\
\text { for buying gear, for } \\
\text { fixing gear and for } \\
\text { general use, fish } \\
\text { for home, bait and } \\
\text { fuel. }\end{array}$ & $\begin{array}{l}\text { No payback, cash } \\
\text { when possible } \\
\text { after sales, with } \\
\text { fish products, } \\
\text { through discounts. }\end{array}$ & & $\begin{array}{l}\text { From Trading } \\
\text { Agents to Fishers: } \\
\text { Cash loans for fuel, } \\
\text { for buying gear } \\
\text { and for general } \\
\text { use, Credit at } \\
\text { Trader's store (i.e. } \\
\text { pay later for } \\
\text { products), 'suki } \\
\text { support' (providing } \\
\text { loans, vessels, } \\
\text { gear, advanced } \\
\text { payments, family } \\
\text { support etc.) and } \\
\text { food. }\end{array}$ & $\begin{array}{l}\text { Deducted from } \\
\text { sales, cash when } \\
\text { possible after } \\
\text { sales, delivery their } \\
\text { catch to the trader. }\end{array}$ & \\
\hline $\begin{array}{l}\text { From Fishers to } \\
\text { Trading Agents: } \\
\text { Fish for home, } \\
\text { cash loans for } \\
\text { general use, } \\
\text { discounts, pay } \\
\text { later options, call } \\
\text { with information on } \\
\text { products and free } \\
\text { products }\end{array}$ & $\begin{array}{l}\text { No payback, cash } \\
\text { the next day, cash } \\
\text { when possible } \\
\text { after sales. }\end{array}$ & & $\begin{array}{l}\text { From Fishers to } \\
\text { Trading Agents: } \\
\text { Cash loan (one } \\
\text { respondent), fish } \\
\text { for home (one } \\
\text { respondent) and } \\
\text { helping secure } \\
\text { trader's vessel on } \\
\text { shore at low tide. }\end{array}$ & $\begin{array}{l}\text { Trading agent } \\
\text { helps in return, } \\
\text { provide loans. }\end{array}$ & \\
\hline
\end{tabular}

